Article

\title{
Tunable Aryl Imidazolium Recyclable Ionic Liquid with Dual Brønsted-Lewis Acid as Green Catalyst for Friedel-Crafts Acylation and Thioesterification
}

\author{
Yi-Jyun Lin ${ }^{1, \dagger}$, Yao-Peng Wu ${ }^{1, \dagger}{ }^{\dagger}$, Mayur Thul ${ }^{1,+}+$, Ming-Wei Hung ${ }^{1}$, Shih-Huan Chou ${ }^{2}$, \\ Wen-Tin Chen ${ }^{3}$, Wesley Lin ${ }^{4}{ }^{(D)}$, Michelle Lin ${ }^{4}$, Daggula Mallikarjuna Reddy ${ }^{1}, \mathrm{Hsin}-\mathrm{Ru} \mathrm{Wu}^{5}$, \\ Wen-Yueh Ho ${ }^{6, *}$ and Shun-Yuan Luo ${ }^{1, *(D)}$ \\ 1 Department of Chemistry, National Chung Hsing University, Taichung 402, Taiwan; \\ jiun16899@yahoo.com.tw (Y.-J.L.); grandy.hchs@gmail.com (Y.-P.W.); mayurthul4@gmail.com (M.T.); \\ wei7521@gmail.com (M.-W.H.); mallikarjuna18.d@gmail.com (D.M.R.) \\ 2 Department of Chemistry, Taipei American School, Taipei 111, Taiwan; 20ryanc@tas.tw \\ 3 Department of Chemistry, Taichung Municipal Chungming Senior High School, Taichung 403, Taiwan; \\ ting2182180@gmail.com \\ 4 Department of Chemistry, Morrison Academy, Taichung 406, Taiwan; linw@mca.org.tw (W.L.); \\ linm5@mca.org.tw (M.L.) \\ 5 Instrumentation Center, MOST, National Tsing Hua University, Hsinchu 30013, Taiwan; \\ hrwu@mx.nthu.edu.tw \\ 6 Department of Cosmetic Science and Institute of Cosmetic Science, Chia Nan University of Pharmacy and \\ Science, Tainan 717, Taiwan \\ * Correspondence: rickho@mail.cnu.edu.tw (W.-Y.H.); syluo@dragon.nchu.edu.tw (S.-Y.L.); \\ Tel.: +886-928502344 (S.-Y.L.) \\ + These authors contributed equally to this work.
}

Received: 13 December 2019; Accepted: 9 January 2020; Published: 15 January 2020 updates

\begin{abstract}
Unique tunable aryl imidazolium ionic liquids successfully catalyzed Friedel-Crafts acylation and thioesterification in sealed tubes. These reactions can form a $\mathrm{C}-\mathrm{C}$ bond and a $\mathrm{C}-\mathrm{S}$ bond with high atom economy. Ionic liquids exhibited high activity and catalyzed essential reactions with good to excellent yields while retaining their catalytic activities for recycling.
\end{abstract}

Keywords: ionic liquids; Friedel-Crafts acylation; thioesterification; recyclable

\section{Introduction}

Ionic liquids outperform organic solvents in industrial processes and are considered as an eco-friendly choice to the broad scope of the organic reactions [1-6]. They are important green solvents that exhibit high thermal stability, recovery, and recycling. They are also a new class of solvents that are expected to be increasingly used by the chemical industry in the next few years, replacing volatile organic solvents. Owing to their low volatility, non-flammability, and thermal stability, ionic liquids can be applied in many operations. Most ionic liquids, such as imidazolium, comprise an organic or inorganic anion and a quaternary ammonium cation [7-10]. Because they are hugely tunable and have remarkable properties, they have become a crucial part in synthesis and catalysis. Most of the interest in ionic liquids concentrates on their ability to change considerably the reactivity of dissolved solutes. The properties of ionic liquids have caused them to be identified as designer solvents, including task specific ionic liquids [11,12]. A comprehensive understanding of the physical characteristics of ionic liquids can increase their industrial use [13]. Ionic liquids have been analyzed owing to their many applications in organic synthesis, analytical chemistry, electrochemistry, separation chemistry, separation technology, polymers, fiber optics, $\mathrm{pH}$ sensors, and others [14,15]. 
In general, electronic effects and polarity of solvents play important roles in the outcomes of the product for Friedel-Crafts reaction. The changing the connected carbon and oxygen atoms were accomplished through para selective functionalization of benzoic acid in the presence of palladium catalyst [16-19]. The aromatic ketones of Friedel-Crafts acylation are a fundamental mediator in a broad range, such as pharmaceutical dyes, fragrances, and agrochemicals [20], and are convenient for use in the synthesis of poly (4-vinyl pyridine)-triflic acid, indium triflate [21,22], perfluoroalkane sulfonic acidic resin is an acid catalyst with catalytic activity for many reactions giving high selectivity. One major drawback of this catalyst is its inefficient swelling by aprotic organic solvents, which generally leads to low reaction rates and others [23]. Iron (III) chloride earns wider acceptance as a useful Lewis acid in Friedel-Crafts acylation [24]. The most exciting feature of our synthesized ionic liquids have an important role in Friedel-Crafts acylation. Previous investigations have reported that ionic liquids exhibit the dual Brønsted and Lewis acidic property, the halogen-free Brønsted-Lewis acidic ionic liquids were synthesized and exploited to catalyze the esterification of caprylic acid with methanol. The novel multifunctional MCM-41 as Brønsted-Lewis acidic ionic liquids were prepared and tested for their catalytic activities in one-pot three-component Mannich reactions [25-27]. Benzoylation of anisole catalyzed by metal triflate and chloroindate (III) by Lewis-acid ionic liquid were used in Friedel-Crafts reaction [28,29]. The consolidation of $\mathrm{sp}^{3}$ alkyl and $\mathrm{sp}^{2}$ aryl substituents at the nitrogen atoms of the imidazolium origin allowed a far greater variety of ionic liquids [30]. These ionic liquids have an $\mathrm{sp}^{2}$ hybridized carbon atoms as an N-substituted heterocycle are synthesized as a novel type of ionic liquids is a renowned catalyst which is moisture insensitive and stable at room temperature, use for a variety of organic transformations, including Friedel-Crafts acylation reactions. The electron-withdrawing group of the aryl ring allows easier deprotonation of imidazolium for forming a stronger Brønsted acid.

Thioesters are important molecules for organic synthesis and are obtained by coupling aldehydes and sulfur surrogates recently [31]. Kita and co-workers described the formation of thioesters from aldehydes [32] and specific pentafluorophenyl disulfide [33]. Takemoto and co-workers reported the expensive carbene-promoted coupling reaction of thiols and aldehydes [34]. Bandgar and co-workers developed that Dess-Martin periodinane and $\mathrm{NaN}_{3}$ promoted to synthesize thio-esters with aldehydes and aryl thiols [35]. Lee and co-workers demonstrated that $\mathrm{FeBr}_{2}$ is able to catalyze synthesis of thioesters from thiols, aldehydes and tert-butyl hydro peroxide (TBHP) in water [36].

\section{Results and Discussion}

Initial studies of $\mathbf{2 a}$ and $\mathbf{3 a}$ determined the optimal reaction conditions (Table 1 ). The study of dual Brønsted-Lewis acidic ionic liquids 1a, 1b, 1c, and 1d of Figure 1 suggested that 1d was the best catalyst of Friedel-Crafts acylation, providing the product 4 a in $74 \%$ yield (Table 1, entries $1-4$ ) $[37,38]$. Increasing the temperature to $100{ }^{\circ} \mathrm{C}$ and $120^{\circ} \mathrm{C}$ with $\mathbf{1 d}$ afforded $4 \mathbf{a}$ in $74 \%$ and $71 \%$ yields, respectively (Table 1, entries 5-6). Lowering the concentration of $1 \mathbf{d}$ to 0.9 equivalent led to higher yield (78\%, Table 1, entry 7$)$, while decreasing it to 0.8 equivalent reduced the reaction yield (73\%, Table 1 , entry 8$)$.

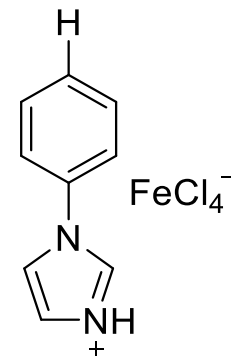

$1 a$<smiles></smiles>

1b<smiles>COc1ccc(-n2cc[nH+]c2)cc1</smiles>

$1 \mathrm{c}$<smiles>O=[N+]([O-])c1ccc(-n2cc[nH+]c2)cc1</smiles>

1d

Figure 1. Tunable aryl imidazolium recyclable ionic liquid 1a-1d with dual activity. 
Table 1. Optimized condition of Friedel-Crafts acylation.<smiles>COc1ccccc1</smiles>

2a<smiles>O=C(Cl)c1ccccc1</smiles>

$3 a$

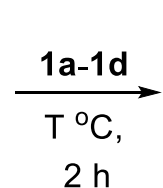

$2 \mathrm{~h}$<smiles>COc1ccc(C(=O)c2ccccc2)cc1</smiles>

$4 a$

\begin{tabular}{cccc}
\hline Entry & IL (equiv.) $^{\boldsymbol{a}}$ & $\mathbf{T}$ & Yield $^{\boldsymbol{b}}$ \\
\hline 1 & $\mathbf{1 a}(1.0)$ & $80^{\circ} \mathrm{C}$ & $57 \%$ \\
2 & $\mathbf{1 b}(1.0)$ & $80^{\circ} \mathrm{C}$ & $32 \%$ \\
3 & $\mathbf{1 c}(1.0)$ & $80^{\circ} \mathrm{C}$ & $72 \%$ \\
4 & $\mathbf{1 d}(1.0)$ & $80^{\circ} \mathrm{C}$ & $74 \%$ \\
5 & $\mathbf{1 d}(1.0)$ & $100{ }^{\circ} \mathrm{C}$ & $74 \%$ \\
6 & $\mathbf{1 d}(1.0)$ & $120^{\circ} \mathrm{C}$ & $71 \%$ \\
7 & $\mathbf{1 d}(0.9)$ & $100{ }^{\circ} \mathrm{C}$ & $78 \%$ \\
8 & $\mathbf{1 d}(0.8)$ & $100{ }^{\circ} \mathrm{C}$ & $73 \%$ \\
\hline
\end{tabular}

${ }^{a}$ Our reaction conditions are anisole (2.0 equiv.), benzoyl chloride (1.0 equiv.) and ionic liquids $1 \mathbf{a}-\mathbf{1 d} .^{b}$ The yields are isolated yields.

\subsection{Friedel-Crafts Acylation}

The scope of Friedel-Crafts reaction with various aryl alkanes and acyl chlorides under optimized reaction conditions was investigated (Table 2, entries 1-8). The Friedel-Crafts reactions with aryl alkanes $\mathbf{2 a}$ and different acyl chloride (3b-3c) under standard conditions were carried out, and the desired products $\mathbf{4 b}$ and $\mathbf{4 c}$ were isolated in $73 \%$ and $68 \%$ yields (Table 2, entries 1,2). Under the same reaction conditions, the Friedel-Crafts reaction in the presence of $\mathbf{2 b}$ and $3 a$ produced $\mathbf{4 d}$ in $83 \%$ yield (Table 1, entry 3). The reaction proceeded very smoothly with $\mathbf{2} \mathbf{b}$ and $\mathbf{3} \mathbf{b}$ under the above conditions to yield the compound $\mathbf{4 e}$ with a $79 \%$ yield (Table 2, entry 4 ). Acyl chloride $\mathbf{3 c}$ reacted with $\mathbf{2 b}$ to afford the corresponding product $\mathbf{4 f}$ in $89 \%$ yield (Table 2, entry 5). Aryl alkane $\mathbf{2 c}$ and acyl chloride 3a were coupled under similar reaction conditions to obtain the product $4 \mathbf{g}$ in $81 \%$ yield (Table 2, entry 6). When the reaction was performed using $\mathbf{2} \mathbf{c}$ and $\mathbf{3 b}$, the product $\mathbf{4 h}$ was afforded in $71 \%$ yield (Table 2, entry 7). Product $\mathbf{4 i}$ was furnished in $70 \%$ yield using $\mathbf{2} \mathbf{c}$ and $\mathbf{3 c}$ (Table 2, entry 8). While doing Friedel-Crafts acylation, $\mathrm{HCl}$ did not affect the reaction, so could not consider to remove $\mathrm{HCl}$ from ionic liquid. It is possible to remove $\mathrm{HCl}$ from an ionic liquid by using a high vacuum or suction pump. 
Table 2. Ionic liquids $1 \mathrm{~d}$ catalyzed Friedel-Crafts acylation with aryl alkanes $\mathbf{2 a} \mathbf{a} \mathbf{2} \mathbf{c}$ and acid chlorides 3a-3c without solvent.<smiles>[R]c1ccccc1</smiles>

2a-2c<smiles>[R]c1ccc(C(=O)Cl)cc1</smiles>

$\mathrm{th}$, $100{ }^{\circ} \mathrm{C}$<smiles>[R]C1=CC=CC(C(=O)c2cccc([R2])c2)=C=C1</smiles>

4b-4i<smiles>Cc1cc(C)cc(C)c1</smiles>

2b<smiles>COc1ccccc1OC</smiles>

2c<smiles>O=C(Cl)c1ccccc1Cl</smiles>

$3 b$<smiles>O=C(Cl)c1ccc(Cl)cc1</smiles>

3c<smiles>COc1ccc(C(=O)c2ccc(Oc3ccc(C(=O)c4ccc(Cl)cc4)cc3)cc2Cl)cc1</smiles><smiles>Cc1cc(C)c(C(=O)c2ccccc2Cl)c(C)c1</smiles>

$4 e$<smiles>Cc1cc(C)c(C(=O)c2ccc(Cl)cc2)c(C)c1</smiles>

$4 f$<smiles>COc1ccc(C(=O)c2ccccc2)cc1OC</smiles><smiles>COc1ccc(C(=O)c2ccccc2Cl)cc1OC</smiles><smiles>COc1ccc(C(=O)c2ccc(Cl)cc2)cc1OC</smiles>

4i

\begin{tabular}{ccccc}
\hline Entry & Aryl Alkane & Acyl Chloride & $\mathbf{t}$ (h) & P (yield) \\
\hline 1 & $\mathbf{2 a}$ & $\mathbf{3 b}$ & 4.0 & $\mathbf{4 b}(73 \%)$ \\
2 & $\mathbf{2 a}$ & $\mathbf{3 c}$ & 4.0 & $\mathbf{4 c}(68 \%)$ \\
3 & $\mathbf{2 b}$ & $\mathbf{3 a}$ & 2.0 & $\mathbf{4 d}(83 \%)$ \\
4 & $\mathbf{2 b}$ & $\mathbf{3 b}$ & 3.5 & $\mathbf{4 e}(79 \%)$ \\
5 & $\mathbf{2 b}$ & $\mathbf{3 c}$ & 2.0 & $\mathbf{4 f}(89 \%)$ \\
6 & $\mathbf{2 c}$ & $\mathbf{3 a}$ & 3.0 & $\mathbf{4 g}(81 \%)$ \\
7 & $\mathbf{2 c}$ & $\mathbf{3 b}$ & 3.5 & $\mathbf{4 h}(71 \%)$ \\
8 & $\mathbf{2 c}$ & $\mathbf{3 c}$ & 3.0 & $\mathbf{4 i}(70 \%)$ \\
\hline
\end{tabular}

To further develop a recyclable catalytic system, the recycling of the $\mathbf{1 d}$ was inspected under the optimized conditions (Figure 2a). After reaction finished, diethyl ether was added. The ionic liquid 1d was recovered from water layer and dried for the next reaction under vacuum. For the first run, the activity of ionic liquid 1d remained same yield (78\%). In the subsequent second (76\%), third (66\%), fourth $(69 \%)$, and fifth $(67 \%)$ cycles, the desired product was still reached with $100 \%$ conversion, when reaction was monitored on TLC plate, the desired product saw without any side product (Figure 2b). 


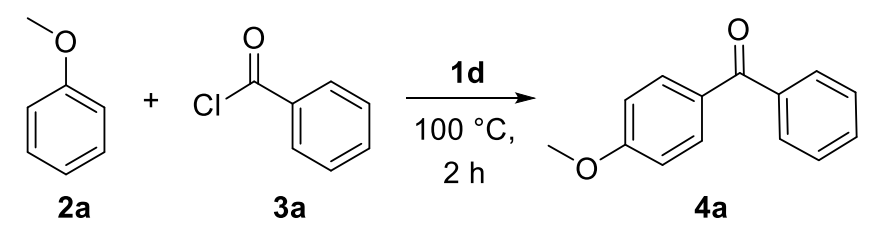

(a)

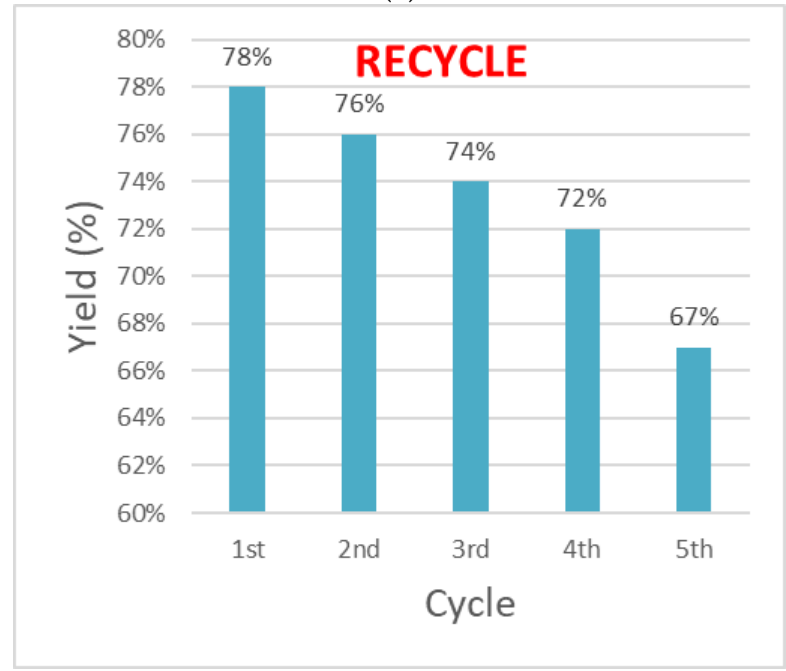

(b)

Figure 2. (a) Friedel-Crafts acylation reaction (b) Recycling of 1d in the synthesis of (4-methoxyphenyl) phenyl-methanone 4 a.

Initially, acyl chloride $\mathbf{2}$ was abstracted the proton of $\mathbf{1 d}$. The acyl chloride cation $\mathbf{A}$ and $\mathbf{1 d}_{\mathbf{a}}$ transformed to intermediate $\mathbf{B}$ by the release of $\mathbf{1} \mathbf{d}_{\mathbf{b}}$. Then, $\mathbf{1} \mathbf{d}_{\mathbf{b}}$ captured the proton of intermediate $\mathbf{B}$ to give intermediate $\mathbf{C}$. Subsequently, $\mathbf{C}$ was transformed into acyl cation $\mathbf{D}$ by the release of $\mathrm{FeCl}_{4}$ anion. Ultimately, the acyl cation $\mathbf{D}$ reacted with aryl alkane $\mathbf{1}$ to form the desired product $\mathbf{3}$ (Figure 3).

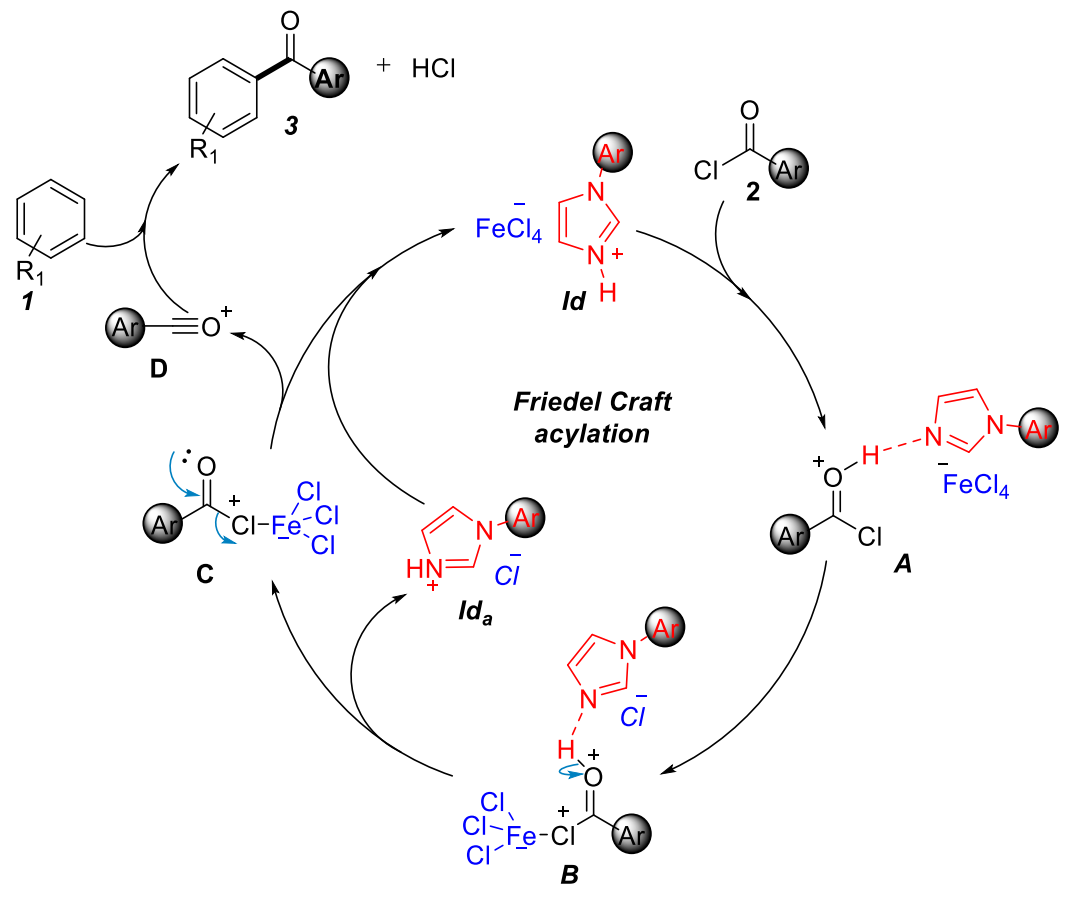

Figure 3. Proposed mechanism of Friedel-Crafts acylation. 


\subsection{Thioesterification}

Initially, benzaldehyde 5a and 1-dodecanethiol $\mathbf{6 a}$ were selected as the model substrates to determine the optimized reaction conditions and the results are summarized in Table 3 . We first examined the source of the ionic liquids 1a-1d (0.025 equivalent) in presence of TBHP as a oxidant at $120{ }^{\circ} \mathrm{C}$ (Table 3, entries 1-4), and 1d was the best catalyst of thioesterification providing the product 7a in $70 \%$ yield (Table 3, entries 1-4). Decreasing the temperature to $100{ }^{\circ} \mathrm{C}$ and increasing the temperature to $140{ }^{\circ} \mathrm{C}$ with $\mathbf{1 d}$ afforded $\mathbf{7 a}$ in similar yields (Table 3, entries 5-6). Decreasing the concentration of $\mathbf{1 d}$ to 0.010 equivalent led to lower yield ( $68 \%$, Table 1 , entry 7$)$, while increasing it to 0.030 equivalent reduced the reaction yield (61\%, Table 1 , entry 8$)$.

Table 3. Optimized condition of thioesterification.

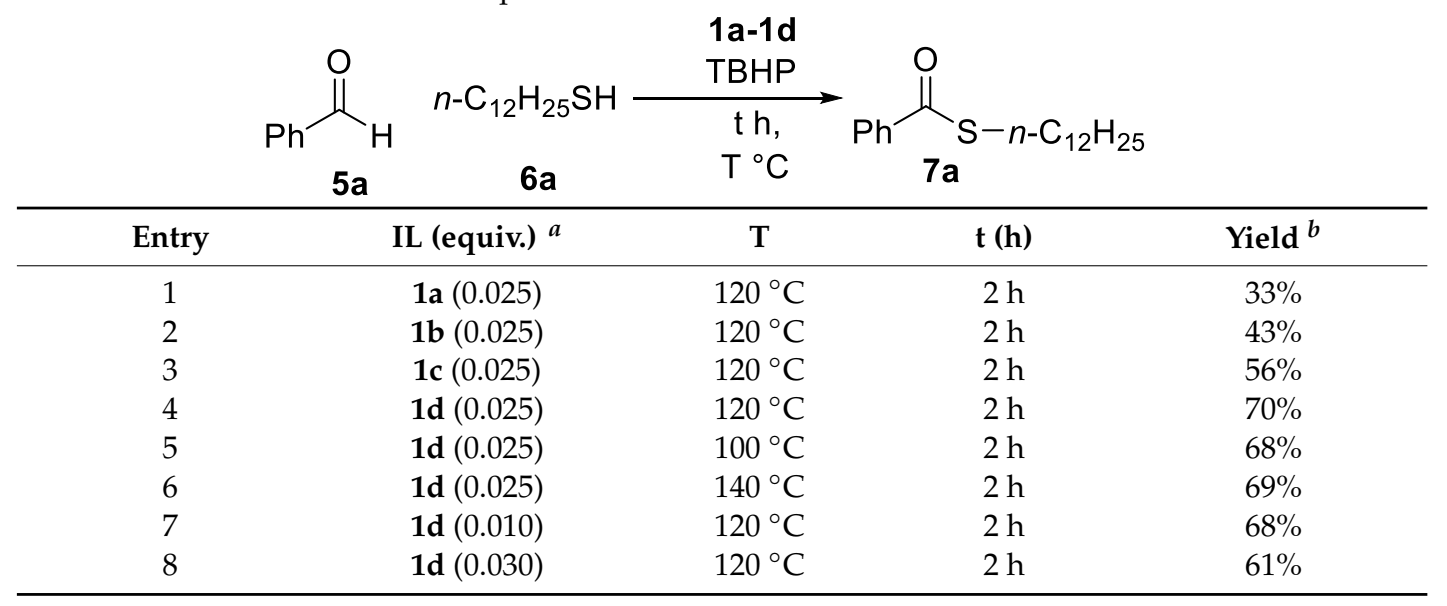

${ }^{a}$ Our reaction conditions are benzalehyde (5.0 equiv.), 1-dodecanethiol (1.0 equiv.), TBHP (2.0 equiv.) and ionic liquid 1a-1d. ${ }^{b}$ The yields are isolated yields.

With these optimized reaction conditions in hand, the scope of the substrates was then studied. The results are summarized in Table 4. A variety of alkyl thiols and aromatic thiols were conducted with aromatic and alkyl aldehydes to afford the corresponding thioesters in good to excellent yields. Aromatic aldehydes bearing electron-donating and electron-withdrawing substituents are all suitable for catalysis. Aldehyde reacted with thiol $\mathbf{6 b}$ and $\mathbf{6 c}$ to give corresponding product $7 \mathbf{b}$ in $88 \%$ and $7 \mathrm{c}$ in $55 \%$ respectively. It is important to note that this system shows good functional group tolerance; chloro (Table 4 , products $\mathbf{7 d}, \mathbf{7 e}$ and $\mathbf{7 f}$ ) are tolerated by reaction condition employed. Aldehydes bearing electron donating substituents underwent thioesterification with alkyl and aryl thiols to give desired product (Table 4, products $\mathbf{7 g}$ and $\mathbf{7 h}$ ). Alkyl thiols were also reacted with alkyl aldehydes to give the corresponding thioesters (Table 4 , products $\mathbf{7 i}, \mathbf{7 j}, \mathbf{7 k}$, and $\mathbf{7 1}$ ). 
Table 4. Ionic liquids $\mathbf{1 d}$ catalyzed coupling reaction with aldehydes $5 \mathbf{a}-\mathbf{5 e}$ and thiols $\mathbf{6 a - 6}$ without solvent.

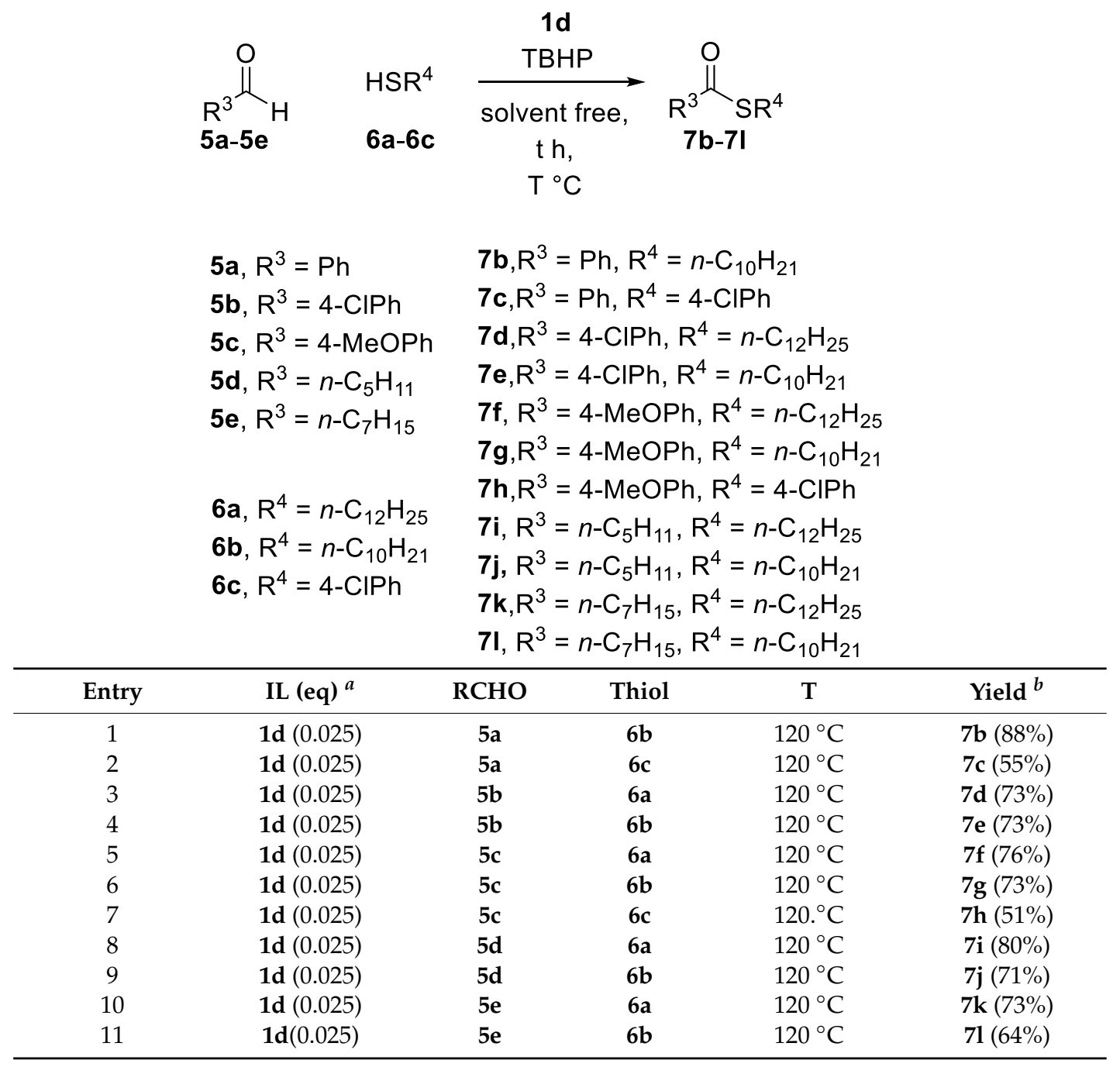

${ }^{a}$ Our reaction conditions are aldehyde (5.0 equiv.), thiol $(1.0 \mathrm{mmol})$, TBHP (2.0 equiv.) and ionic liquid $1 \mathrm{~d} .{ }^{b}$ The yields are isolated yields.

In this method, the recovery of ionic liquid $1 \mathrm{~d}$ ranges from $63-70 \%$ yields. The catalytic activity was examined by thioesterification of thiols at $120^{\circ} \mathrm{C}$ for $1 \mathrm{~h}$ (Figure 4a). The results are presented in (Figure $4 \mathrm{~b}$ ). Ionic liquid was recovered and reused up to five times with only slightly decreased catalytic activity.

Based on the above experimental results, a plausible mechanism is proposed in Figure 5. When 1d is reacted with TBHP, and t-BuOO radical is generated at the time. Initially benzaldehyde reacted with ionic liquid 1d, which would lead to intermediate 3 . Then thiols react with intermediate 3 to give 4 . A hydrogen atom is then abstracted from aldehyde to give an acyl radical. Further t-BuOO radical reacted with 4 to give complex 5 and then hydroxyl radicle II Reacts with 5 to give the final product $\mathbf{6}$. 


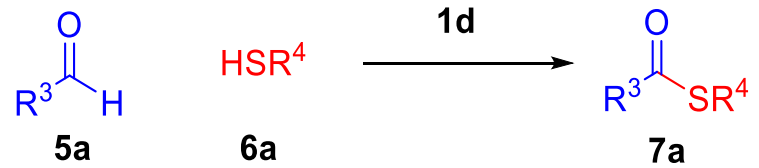

(a)

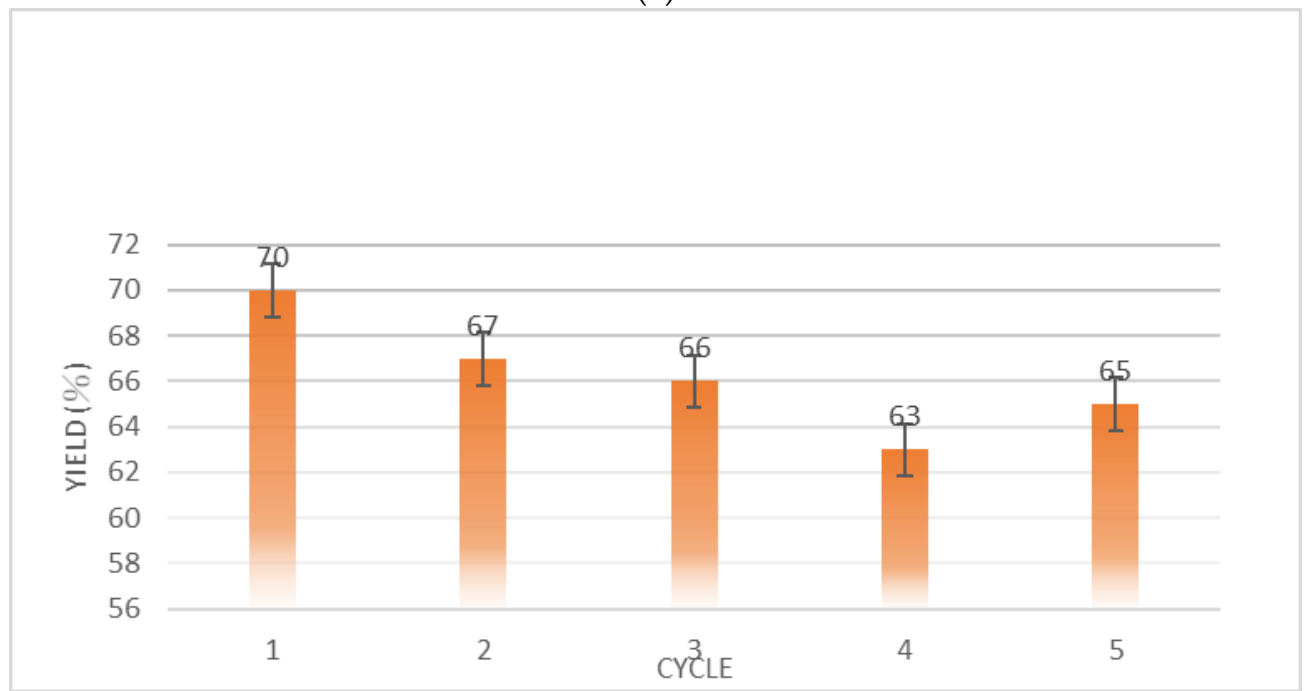

(b)

Figure 4. (a) Thioesterification reaction of thiols (b) Recycling of ld in the synthesis of S-Dodecyl benzothioate.

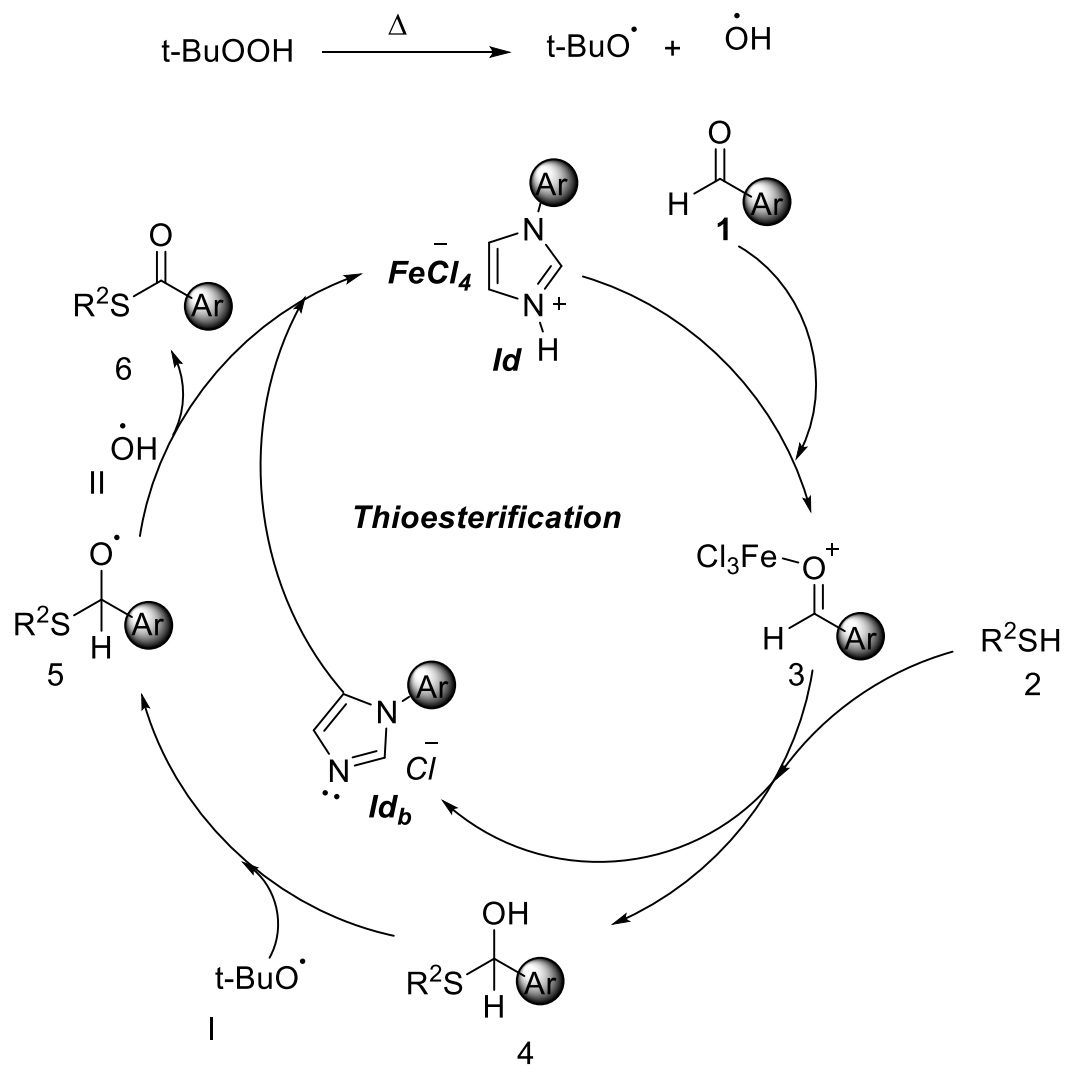

Figure 5. Proposed mechanism of thioesterification. 


\section{Materials and Methods}

The reactions were conducted in flame-dried glassware, under the nitrogen atmosphere. Acetonitrile and dichloromethane were purified and dried from a safe purification system containing activated $\mathrm{Al}_{2} \mathrm{O}_{3}$. All reagents obtained from commercial sources were used without purification unless otherwise mentioned. Flash column chromatography was carried out on Silica Gel 60. TLC was performed on pre-coated glass plates of Silica Gel 60 F254 detection was executed by spraying with a solution of $\mathrm{Ce}\left(\mathrm{NH}_{4}\right)_{2}\left(\mathrm{NO}_{3}\right)_{6}(0.5 \mathrm{~g}),\left(\mathrm{NH}_{4}\right)_{6} \mathrm{Mo}_{7} \mathrm{O}_{24}(24.0 \mathrm{~g})$, and $\mathrm{H}_{2} \mathrm{SO}_{4}(28.0 \mathrm{~mL})$ in water $(500.0 \mathrm{~mL})$ and subsequent heating on a hot plate. Optical rotations were measured at $589 \mathrm{~nm}(\mathrm{Na}),{ }^{1} \mathrm{H},{ }^{13} \mathrm{C} \mathrm{NMR}$, DEPT, ${ }^{1} \mathrm{H}_{-}{ }^{1} \mathrm{H}$ COSY, ${ }^{1} \mathrm{H}_{-}{ }^{13} \mathrm{C}$ COSY, and NOESY spectra were recorded with $400 \mathrm{MHz}$ instruments. Chemical shifts are in ppm from $\mathrm{Me}_{4} \mathrm{Si}$ generated from the $\mathrm{CDCl}_{3}$ lock signal at $\delta 7.26$. IR spectra were taken with a FT-IR spectrometer using $\mathrm{NaCl}$ plates. Mass spectra were analyzed on instrument with an EI, ESI, APCI, and FAB source.

(4-Methoxyphenyl)-phenylmethanone (4a). To a solution of aryl alkane 2a (217 $\mu \mathrm{L}, 2 \mathrm{mmol})$, acyl chloride 3a $(116 \mu \mathrm{L}, 1 \mathrm{mmol})$, and ionic liquid $1 \mathrm{~d}(349 \mathrm{mg}, 0.9 \mathrm{mmol})$ were stirred at $100{ }^{\circ} \mathrm{C}$ for two hours. After cooling, the reaction mixture was washed by diethyl ether $(2 \times 40 \mathrm{~mL})$. The diethyl ether layer was decanted, extracted with water, aqueous $\mathrm{NaHCO}_{3}$, and brine, and dried over $\mathrm{MgSO}_{4}$. After filtration, the organic solvent was then removed on a rotary evaporator. The residue was purified by flash chromatography to give the desired product $4 \mathrm{a}(165 \mathrm{mg}, 78 \%)$ as a light yellow oil. $\mathrm{R}_{\mathrm{f}} 0.37$ (EtOAc/Hex $=1 / 6)$. IR $(\mathrm{NaCl})$ v 3060, 3006, 2840, 1651, 1597, 1508, $1171 \mathrm{~cm}^{-1} ;{ }^{1} \mathrm{H}$ NMR (Supplementary Materials) $\left(400 \mathrm{MHz} \mathrm{CDCl}_{3}\right) \delta 7.82(\mathrm{~d}, J=8.8 \mathrm{~Hz}, 2 \mathrm{H}), 7.74(\mathrm{~d}, J=6.8 \mathrm{~Hz}, 2 \mathrm{H}), 7.55(\mathrm{t}, J=7.4 \mathrm{~Hz}, 1 \mathrm{H}), 7.45(\mathrm{t}, J=$ $7.6 \mathrm{~Hz}, 2 \mathrm{H}), 6.95(\mathrm{~d}, J=9.2 \mathrm{~Hz}, 2 \mathrm{H}), 3.86(\mathrm{~s}, 3 \mathrm{H}) ;{ }^{13} \mathrm{C} \mathrm{NMR}\left(101 \mathrm{MHz}, \mathrm{CDCl}_{3}\right) \delta 195.4,163.1,138.2,132.4$, 131.8, 130.0, 129.6, 128.1, 113.4, 55.4; HRMS (EI, $\mathrm{M}^{+}$) calculated for $\mathrm{C}_{14} \mathrm{H}_{12} \mathrm{O}_{2}$ 212.0837, found 212.0834.

(2-Chlorophenyl)-(4-methoxyphenyl) methanone (4b). To a solution of aryl alkane $2 \mathbf{a}(217 \mu \mathrm{L}, 2 \mathrm{mmol})$, acyl chloride $3 \mathbf{b}(126 \mu \mathrm{L}, 1 \mathrm{mmol})$, and ionic liquid $1 \mathbf{d}(349 \mathrm{mg}, 0.9 \mathrm{mmol})$ were stirred at $100{ }^{\circ} \mathrm{C}$ for four hours. After cooling, the reaction mixture was washed by diethyl ether $(2 \times 40 \mathrm{~mL})$. The diethyl ether layer was decanted, extracted with water, aqueous $\mathrm{NaHCO}_{3}$, and brine, and dried over $\mathrm{MgSO}_{4}$. After filtration, the organic solvent was removed on a rotary evaporator. The residue was purified by flash chromatography to give the desired product $4 \mathrm{~b}(180 \mathrm{mg}, 73 \%)$ as a light yellow solid. $\mathrm{R}_{\mathrm{f}} 0.40$ $\left(\right.$ EtOAc/Hex = 1/4); $\operatorname{mp} 71-74{ }^{\circ} \mathrm{C}$; IR $(\mathrm{NaCl})$ v 3068, 3009, 2964, 2840, 1659, 1595, 1508, 1464, 1149, 843 $\mathrm{cm}^{-1} ;{ }^{1} \mathrm{H}$ NMR $\left(400 \mathrm{MHz}, \mathrm{CDCl}_{3}\right) \delta 7.79(\mathrm{~d}, J=9.2 \mathrm{~Hz}, 2 \mathrm{H}), 7.47-7.38(\mathrm{~m}, 2 \mathrm{H}), 7.37-7.36(\mathrm{~m}, 1 \mathrm{H}), 7.35$ $(\mathrm{d}, J=1.2 \mathrm{~Hz}, 1 \mathrm{H}), 6.94(\mathrm{~d}, J=9.2 \mathrm{~Hz}, 2 \mathrm{H}), 3.88(\mathrm{~s}, 3 \mathrm{H}) ;{ }^{13} \mathrm{C} \mathrm{NMR}\left(101 \mathrm{MHz}, \mathrm{CDCl}_{3}\right) \delta 193.8,164.1$, 139.0, 132.5, 131.0, 130.8, 129.9, 129.4, 128.8, 126.6, 113.8, 55.5; HRMS (ESI, $\mathrm{M}+\mathrm{H}^{+}$) calculated for $\mathrm{C}_{14} \mathrm{H}_{12} \mathrm{ClO}_{2} 247.0526$, found 247.0525

(4-Chlorophenyl)-(4-methoxyphenyl)methanone (4c). To a solution of aryl alkane 2a (217 $\mu \mathrm{L}, 2 \mathrm{mmol})$, acyl chloride 3c $(127 \mu \mathrm{L}, 1 \mathrm{mmol})$, and ionic liquid $1 \mathrm{~d}(349 \mathrm{mg}, 0.9 \mathrm{mmol})$ were stirred at $100{ }^{\circ} \mathrm{C}$ for four hours. After cooling, the reaction mixture was washed by diethyl ether $(2 \times 40 \mathrm{~mL})$. The diethyl ether layer was decanted, extracted with water, aqueous $\mathrm{NaHCO}_{3}$, and brine, and dried over $\mathrm{MgSO}_{4}$. After filtration, the organic solvent was removed on a rotary evaporator. The residue was purified by flash chromatography to give the desired product $4 \mathrm{c}(168 \mathrm{mg}, 68 \%)$ as a light yellow solid. $\mathrm{R}_{\mathrm{f}} 0.37$ $\left(\right.$ EtOAc/Hex = 1/4); $\mathrm{mp} 119-122{ }^{\circ} \mathrm{C}$; IR $(\mathrm{NaCl})$ v 2962, 2934, 2841, 1641, 1604, 1509, 1461, 1148, $760 \mathrm{~cm}^{-1}$; ${ }^{1} \mathrm{H} \mathrm{NMR}\left(400 \mathrm{MHz}, \mathrm{CDCl}_{3}\right) \delta 7.80(\mathrm{~d}, J=8.4 \mathrm{~Hz}, 2 \mathrm{H}), 7.71(\mathrm{~d}, J=8.4 \mathrm{~Hz}, 2 \mathrm{H}), 7.45(\mathrm{~d}, J=8.4 \mathrm{~Hz}, 2 \mathrm{H})$, $6.97(\mathrm{~d}, J=8.8 \mathrm{~Hz}, 2 \mathrm{H}), 3.89(\mathrm{~s}, 3 \mathrm{H}) ;{ }^{13} \mathrm{C} \mathrm{NMR}\left(101 \mathrm{MHz}, \mathrm{CDCl}_{3}\right) \delta 194.2,163.3,138.2,136.5,132.4,131.1$, 129.7, 128.5, 113.6, 55.5; HRMS (ESI, $\mathrm{M}+\mathrm{H}^{+}$) calculated for $\mathrm{C}_{14} \mathrm{H}_{12} \mathrm{ClO}_{2}$ 247.0526, found 247.0523.

(2,4,6-Trimethylphenyl)-phenylmethanone (4d). To a solution of aryl alkane $\mathbf{2 b}(278 \mu \mathrm{L}, 2 \mathrm{mmol})$, acyl chloride $3 \mathrm{a}(116 \mu \mathrm{L}, 1 \mathrm{mmol})$ and ionic liquid $5(349 \mathrm{mg}, 0.9 \mathrm{mmol})$ were stirred at $100{ }^{\circ} \mathrm{C}$ for $2 \mathrm{hours}$. After cooling, the reaction mixture was washed by diethyl ether $(2 \times 40 \mathrm{~mL})$. The diethyl ether layer was decanted, extracted with water, aqueous $\mathrm{NaHCO}_{3}$, and brine, and dried over $\mathrm{MgSO}_{4}$. After filtration, the organic solvent was then removed on a rotary evaporator. The residue was purified by flash 
chromatography to give the desired product $4 \mathrm{~d}(186 \mathrm{mg}, 83 \%)$ as a light yellow oil. $\mathrm{R}_{\mathrm{f}} 0.40$ (EtOAc/Hex = 1/12); IR (NaCl) v 3061, 2951, 2921, 2860, 1671, 1449, $1380 \mathrm{~cm}^{-1},{ }^{1} \mathrm{H} \mathrm{NMR}\left(400 \mathrm{MHz}, \mathrm{CDCl}_{3}\right) \delta 7.81(\mathrm{~d}$, $J=7.2 \mathrm{~Hz}, 2 \mathrm{H}), 7.57(\mathrm{t}, J=7.2 \mathrm{~Hz}, 1 \mathrm{H}), 7.44(\mathrm{t}, J=7.8 \mathrm{~Hz}, 2 \mathrm{H}), 6.90(\mathrm{~s}, 2 \mathrm{H}), 2.34(\mathrm{~s}, 3 \mathrm{H}), 2.09(\mathrm{~s}, 6 \mathrm{H}) ;{ }^{13} \mathrm{C}$ NMR $\left(101 \mathrm{MHz} \mathrm{CDCl}_{3}\right) \delta 200.8,138.5,137.3,136.8,134.1,133.5,129.4,128.7,128.3,21.1,19.3$; HRMS (ESI, $\mathrm{M}+\mathrm{H}^{+}$) calculated for $\mathrm{C}_{16} \mathrm{H}_{17} \mathrm{O} 225.1279$, found 225.1281 .

(2-Chlorophenyl)-(2,4,6-trimethylphenyl) methanone (4e). To a solution of aryl alkane $\mathbf{2 b}(278 \mu \mathrm{L}, 2 \mathrm{mmol})$, acyl chloride $3 \mathbf{b}(126 \mu \mathrm{L}, 1 \mathrm{mmol})$, and ionic liquid $\mathbf{1 d}(349 \mathrm{mg}, 0.9 \mathrm{mmol})$ were stirred at $100{ }^{\circ} \mathrm{C}$ for 3.5 hours. After cooling, the reaction mixture was washed by diethyl ether $(2 \times 40 \mathrm{~mL})$. The diethyl ether layer was decanted, extracted with water, aqueous $\mathrm{NaHCO}_{3}$, and brine, and dried over $\mathrm{MgSO}_{4}$. After filtration, the organic solvent was then removed on a rotary evaporator. The residue was purified by flash chromatography to give the desired product $4 \mathrm{e}(204 \mathrm{mg}, 79 \%)$ as a light orange solid. $\mathrm{R}_{\mathrm{f}} 0.53$ (EtOAc/Hex = 1/10). mp 101-102 ${ }^{\circ} \mathrm{C}$; IR $(\mathrm{NaCl})$ v 2917, 1671, 1610, 1584, $1436 \mathrm{~cm}^{-1}$; ${ }^{1} \mathrm{H} \mathrm{NMR}(400 \mathrm{MHz}$, $\left.\mathrm{CDCl}_{3}\right) \delta 7.47(\mathrm{~d}, J=7.8 \mathrm{~Hz}, 2 \mathrm{H}), 7.41(\mathrm{t}, J=7.7 \mathrm{~Hz}, 1 \mathrm{H}), 7.26(\mathrm{t}, J=7.5 \mathrm{~Hz}, 1 \mathrm{H}), 6.87(\mathrm{~s}, 2 \mathrm{H}), 2.31(\mathrm{~s}, 3 \mathrm{H})$, $2.12(\mathrm{~s}, 6 \mathrm{H}) ;{ }^{13} \mathrm{C} \mathrm{NMR}\left(101 \mathrm{MHz}, \mathrm{CDCl}_{3}\right) \delta 198.9,139.3,137.6,137.3,135.0,133.2,132.7,131.7,131.4$, 128.8, 126.8, 21.1, 19.7; HRMS (ESI, $\mathrm{M}+\mathrm{Na}^{+}$) calculated for $\mathrm{C}_{16} \mathrm{H}_{15} \mathrm{ClONa}$ 281.0709, found 281.0710.

(4-Chlorophenyl)-(2,4,6-trimethylphenyl)methanone (4f). To a solution of aryl alkane $\mathbf{2 b}(278 \mu \mathrm{L}, 2 \mathrm{mmol})$, acyl chloride $3 \mathrm{c}(127 \mu \mathrm{L}, 1 \mathrm{mmol})$, and ionic liquid $1 \mathrm{~d}(349 \mathrm{mg}, 0.9 \mathrm{mmol})$ were stirred at $100{ }^{\circ} \mathrm{C}$ for two hours. After cooling, the reaction mixture was washed by diethyl ether $(2 \times 40 \mathrm{~mL})$. The diethyl ether layer was decanted, extracted with water, aqueous $\mathrm{NaHCO}_{3}$, and brine, and dried over $\mathrm{MgSO}_{4}$. After filtration, the organic solvent was then removed on a rotary evaporator. The residue was purified by flash chromatography to give the desired product $4 \mathrm{f}(230 \mathrm{mg}, 89 \%)$ as a white solid. $\mathrm{R}_{\mathrm{f}} 0.61$ (EtOAc/Hex $=1 / 10) . \mathrm{mp} 64-65^{\circ} \mathrm{C} ; \mathrm{IR}(\mathrm{NaCl})$ v 2921, 1673, $1586 \mathrm{~cm}^{-1} ;{ }^{1} \mathrm{H}$ NMR $\left(400 \mathrm{MHz}, \mathrm{CDCl}_{3}\right) \delta 7.74(\mathrm{~d}, J=8.4$ $\mathrm{Hz}, 2 \mathrm{H}), 7.41(\mathrm{~d}, J=8.5 \mathrm{~Hz}, 2 \mathrm{H}), 6.90(\mathrm{~s}, 2 \mathrm{H}), 2.33(\mathrm{~s}, 3 \mathrm{H}), 2.07(\mathrm{~s}, 6 \mathrm{H}) ;{ }^{13} \mathrm{C} \mathrm{NMR}\left(101 \mathrm{MHz}, \mathrm{CDCl}_{3}\right) \delta$ 199.5, 140.1, 138.7, 136.3, 135.6, 134.1, 130.7, 129.1, 128.4, 21.1, 19.3; HRMS (APCI, M + $\mathrm{H}^{+}$) calculated for $\mathrm{C}_{16} \mathrm{H}_{16} \mathrm{ClO} 259.0890$, found 259.0888 .

(3,4-Dimethoxyphenyl)-phenylmethanone (4g). To a solution of aryl alkane $2 \mathrm{c}(256 \mu \mathrm{L}, 2 \mathrm{mmol})$, acyl chloride 3a $(116 \mu \mathrm{L}, 1 \mathrm{mmol})$ and ionic liquid $1 \mathbf{d}(349 \mathrm{mg}, 0.9 \mathrm{mmol})$ were stirred at $100{ }^{\circ} \mathrm{C}$ for three hours. After cooling, the reaction mixture was washed by diethyl ether $(2 \times 40 \mathrm{~mL})$. The diethyl ether layer was decanted, extracted with water, aqueous $\mathrm{NaHCO}_{3}$, and brine, and dried over $\mathrm{MgSO}_{4}$. After filtration, the organic solvent was then removed on a rotary evaporator. The residue was purified by flash chromatography to give the desired product $4 \mathrm{~g}(196 \mathrm{mg}, 81 \%)$ as a white solid. $\mathrm{R}_{\mathrm{f}} 0.45(\mathrm{EtOAc} / \mathrm{Hex}=$ 1/4); mp 100-101 ${ }^{\circ} \mathrm{C}$; IR (NaCl) v 3079, 3003, 2960, 2839, 1649, 1594, 1272, $1130 \mathrm{~cm}^{-1} ;{ }^{1} \mathrm{H} \mathrm{NMR}(400 \mathrm{MHz}$, $\left.\mathrm{CDCl}_{3}\right) \delta 7.75(\mathrm{~d}, J=8.2 \mathrm{~Hz}, 2 \mathrm{H}), 7.55(\mathrm{t}, J=7.4 \mathrm{~Hz}, 1 \mathrm{H}), 7.48(\mathrm{~d}, J=2.0 \mathrm{~Hz}, 1 \mathrm{H}), 7.46(\mathrm{t}, J=7.5 \mathrm{~Hz}, 2 \mathrm{H})$, $7.36(\mathrm{dd}, J=8.3,2.0 \mathrm{~Hz}, 1 \mathrm{H}), 6.88(\mathrm{~d}, J=8.4 \mathrm{~Hz}, 1 \mathrm{H}), 3.94(\mathrm{~s}, 3 \mathrm{H}), 3.92(\mathrm{~s}, 3 \mathrm{H}) ;{ }^{13} \mathrm{C} \mathrm{NMR}(101 \mathrm{MHz}$, $\left.\mathrm{CDCl}_{3}\right) \delta 195.4,152.9,148.9,138.1,131.7,130.0,129.6,128.0,125.4,111.9,109.6,55.9 ;$ HRMS (ESI, M + $\mathrm{Na}^{+}$) calculated for $\mathrm{C}_{15} \mathrm{H}_{14} \mathrm{O}_{3} \mathrm{Na} 265.0841$, found 265.0844 .

(2-Chlorophenyl)-(3,4-dimethoxyphenyl) methanone (4h). To a solution of aryl alkane $2 \mathrm{c}(256 \mu \mathrm{L}, 2 \mathrm{mmol})$, acyl chloride $3 \mathbf{b}(126 \mu \mathrm{L}, 1 \mathrm{mmol})$, and ionic liquid $\mathbf{1 d}(349 \mathrm{mg}, 0.9 \mathrm{mmol})$ were stirred at $100{ }^{\circ} \mathrm{C}$ for 3.5 hours. After cooling, the reaction mixture was washed by diethyl ether $(2 \times 40 \mathrm{~mL})$. The diethyl ether layer was decanted, extracted with water, aqueous $\mathrm{NaHCO}_{3}$, and brine, and dried over $\mathrm{MgSO}_{4}$. After filtration, the organic solvent was then removed on a rotary evaporator. The residue was purified by flash chromatography to give the desired product $4 \mathrm{~h}(196 \mathrm{mg}, 71 \%)$ as a light yellow solid. $\mathrm{R}_{\mathrm{f}} 0.34$ $($ EtOAc/Hex $=1 / 2) \cdot \operatorname{mp} 142-143{ }^{\circ} \mathrm{C}$; IR $(\mathrm{NaCl})$ v 3079, 2936, 2840, 1659, 1592, 1513, 1464, 1418, 1133 $\mathrm{cm}^{-1} ;{ }^{1} \mathrm{H}$ NMR $\left(400 \mathrm{MHz}, \mathrm{CDCl}_{3}\right) \delta 7.56(\mathrm{~d}, J=2.0 \mathrm{~Hz}, 1 \mathrm{H}), 7.45-7.37(\mathrm{~m}, 2 \mathrm{H}), 7.34(\mathrm{t}, J=1.0 \mathrm{~Hz}, 1 \mathrm{H})$, $7.33(\mathrm{~d}, J=1.1 \mathrm{~Hz}, 1 \mathrm{H}), 7.19(\mathrm{dd}, J=8.4,2.0 \mathrm{~Hz}, 1 \mathrm{H}), 6.82(\mathrm{~d}, J=8.4 \mathrm{~Hz}, 1 \mathrm{H}), 3.92(\mathrm{~d}, J=1.8 \mathrm{~Hz}, 6 \mathrm{H})$; ${ }^{13} \mathrm{C}$ NMR $\left(101 \mathrm{MHz} \mathrm{CDCl}_{3}\right) \delta 193.8,153.9,149.2,138.8,131.0,130.7,129.9,129.4,128.8,126.5,126.3$, 110.7, 109.9, 56.1, 55.9; HRMS (ESI, $\mathrm{M}+\mathrm{H}^{+}$) calculated for $\mathrm{C}_{15} \mathrm{H}_{14} \mathrm{ClO}_{3}$ 277.0631, found 277.0632. 
(4-Chlorophenyl)-(3,4-dimethoxyphenyl)methanone (4i). To a solution of aryl alkane $2 \mathrm{c}(256 \mu \mathrm{L}, 2 \mathrm{mmol})$, acyl chloride 3c $(127 \mu \mathrm{L}, 1 \mathrm{mmol})$, and ionic liquid $1 \mathrm{~d}(349 \mathrm{mg}, 0.9 \mathrm{mmol})$ were stirred at $100{ }^{\circ} \mathrm{C}$ for three hours. After cooling, the reaction mixture was extracted by ethyl acetate $(2 \times 40 \mathrm{~mL})$. The ethyl acetate layer was decanted, washed with water, aqueous $\mathrm{NaHCO}_{3}$, and brine, and dried over $\mathrm{MgSO}_{4}$. The residue was purified by flash chromatography to give the desired product $4 \mathbf{i}(193 \mathrm{mg}, 70 \%)$ as a white solid. $\mathrm{R}_{\mathrm{f}} 0.28(\mathrm{EtOAc} / \mathrm{Hex}=1 / 4) . \mathrm{mp} 113-114{ }^{\circ} \mathrm{C}$; IR $(\mathrm{NaCl})$ v 2935, 2839, 1649, 1594, 1514, 1272 $\mathrm{cm}^{-1} ;{ }^{1} \mathrm{H}$ NMR $\left(400 \mathrm{MHz}, \mathrm{CDCl}_{3}\right) \delta 7.72(\mathrm{~d}, J=8.4 \mathrm{~Hz}, 2 \mathrm{H}), 7.48-7.46(\mathrm{~m}, 2 \mathrm{H}), 7.45-7.44(\mathrm{~m}, 1 \mathrm{H}), 7.34$ $(\mathrm{dd}, J=8.0,2.0 \mathrm{~Hz}, 1 \mathrm{H}), 6.90(\mathrm{~d}, J=8.4 \mathrm{~Hz}, 1 \mathrm{H}), 3.97(\mathrm{~s}, 3 \mathrm{H}), 3.95(\mathrm{~s}, 3 \mathrm{H}) ;{ }^{13} \mathrm{C} \mathrm{NMR}\left(101 \mathrm{MHz}, \mathrm{CDCl}_{3}\right) \delta$ $193.8,152.9,148.8,137.9,136.2,130.9,129.5,128.2,125.1,111.6,109.5,55.8,55.7 ; \mathrm{HRMS}\left(\mathrm{ESI}, \mathrm{M}+\mathrm{H}^{+}\right)$ calculated for $\mathrm{C}_{15} \mathrm{H}_{14} \mathrm{ClO}_{3} 277.0632$, found 277.0656 .

S-Dodecyl benzothioate (7a). To a solution of thiol $6 \mathbf{a}(240 \mu \mathrm{L}, 1 \mathrm{mmol})$, aldehyde 5 a $(510 \mu \mathrm{L}, 5 \mathrm{mmol})$, tert-butyl hydroperoxide $(277 \mu \mathrm{L}, 2 \mathrm{mmol})$, and ionic liquid $1 \mathrm{~d}(9.7 \mathrm{mg}, 0.025 \mathrm{mmol})$ were stirred at $120{ }^{\circ} \mathrm{C}$ for one hour in a sealed tube. After cooling, the reaction mixture was extracted with ethyl acetate $(3 \times 20 \mathrm{~mL})$. The combined organic layers were dried over anhydrous $\mathrm{MgSO}_{4}$, filtered and concentrated. The residue was purified by flash chromatography to give the desire product $7 \mathbf{a}(214 \mathrm{mg}$, $70 \%$ yield) as a colorless liquid. $\mathrm{R}_{\mathrm{f}} 0.36$ (Hexane). IR $(\mathrm{NaCl}) \mathrm{v} 3063,3030,2925,2854,1666,1597,1449$, 1377, 1027, $1001 \mathrm{~cm}^{-1}$; ${ }^{1} \mathrm{H}$ NMR $\left(400 \mathrm{MHz}, \mathrm{CDCl}_{3}\right) \delta 7.97(\mathrm{dd}, J=8.4,1.2 \mathrm{~Hz}, 2 \mathrm{H}), 7.52(\mathrm{t}, J=7.4 \mathrm{~Hz}, 1 \mathrm{H})$, $7.41(\mathrm{t}, J=7.6 \mathrm{~Hz}, 2 \mathrm{H}), 3.06(\mathrm{t}, J=7.4 \mathrm{~Hz}, 2 \mathrm{H}), 1.72-1.62(\mathrm{~m}, 2 \mathrm{H}), 1.46-1.38(\mathrm{~m}, 2 \mathrm{H}), 1.27(\mathrm{~s}, 16 \mathrm{H}), 0.89(\mathrm{t}$, $J=7.0 \mathrm{~Hz}, 3 \mathrm{H}) ;{ }^{13} \mathrm{C} \mathrm{NMR}\left(101 \mathrm{MHz}, \mathrm{CDCl}_{3}\right) \delta 191.7,137.1,133.0,128.4,127.0,31.9,29.6,29.5,29.4,29.3$, 29.1, 28.9, 28.88, 22.6, 14.0; HRMS (FAB, $\mathrm{M}+\mathrm{H}^{+}$) calculated for $\mathrm{C}_{19} \mathrm{H}_{31}$ OS 307.2096, found 307.2087.

S-Decyl benzothioate (7b). To a solution of thiol $\mathbf{6 b}(212 \mu \mathrm{L}, 1 \mathrm{mmol})$, aldehyde $5 \mathbf{a}(510 \mu \mathrm{L}, 5 \mathrm{mmol})$, tert-butyl hydroperoxide $(277 \mu \mathrm{L}, 2 \mathrm{mmol})$, and ionic liquid $1 \mathrm{~d}(9.7 \mathrm{mg}, 0.025 \mathrm{mmol})$ were stirred at $120^{\circ} \mathrm{C}$ for 1 hour in a sealed tube. After cooling, the reaction mixture was extracted with ethyl acetate $(3 \times 20 \mathrm{~mL})$. The combined organic layers were dried over anhydrous $\mathrm{MgSO}_{4}$, filtered and concentrated. The residue was purified by flash chromatography to give the desire product $7 \mathbf{b}(245 \mathrm{mg}, 88 \%$ yield $)$ as a colorless liquid. $R_{\mathrm{f}} 0.30$ (Hexane). IR (NaCl) v 3063, 3031, 2926, 2854, 1666, 1597, 1449, 1377, 1027, $1001 \mathrm{~cm}^{-1} ;{ }^{1} \mathrm{H}$ NMR $\left(400 \mathrm{MHz}, \mathrm{CDCl}_{3}\right) \delta 7.97(\mathrm{~d}, J=7.2 \mathrm{~Hz}, 2 \mathrm{H}), 7.53(\mathrm{t}, J=7.4 \mathrm{~Hz}, 1 \mathrm{H}), 7.42(\mathrm{t}, J=7.8$ $\mathrm{Hz}, 2 \mathrm{H}), 3.06(\mathrm{t}, J=7.4 \mathrm{~Hz}, 2 \mathrm{H}), 1.63-1.71(\mathrm{~m}, 2 \mathrm{H}), 1.46-1.38(\mathrm{~m}, 2 \mathrm{H}), 1.27(\mathrm{~s}, 12 \mathrm{H}), 0.89(\mathrm{t}, J=6.8 \mathrm{~Hz}$, $3 \mathrm{H}) ;{ }^{13} \mathrm{C} \mathrm{NMR}\left(101 \mathrm{MHz}, \mathrm{CDCl}_{3}\right) \delta 191.9,137.2,133.0,128.4,127.1,31.8,29.5,29.49,29.45,29.2,29.1$, 29.0, 28.9, 22.6, 14.0; HRMS (ESI, $\mathrm{M}+\mathrm{Na}^{+}$) calculated for $\mathrm{C}_{17} \mathrm{H}_{26} \mathrm{NaOS} 301.1602$, found 301.1606.

S-(4-Chlorophenyl) benzothioate (7c). To a solution of thiol 6c (145 mg, $1 \mathrm{mmol})$, aldehyde $5 \mathbf{a}(510 \mu \mathrm{L}$, $5 \mathrm{mmol})$, tert-butyl hydroperoxide $(277 \mu \mathrm{L}, 2 \mathrm{mmol})$, and ionic liquid $1 \mathrm{~d}(9.7 \mathrm{mg}, 0.025 \mathrm{mmol})$ were stirred at $120{ }^{\circ} \mathrm{C}$ for one hour in a sealed tube. After cooling, the reaction mixture was extracted with ethyl acetate $(3 \times 20 \mathrm{~mL})$. The combined organic layers were dried over anhydrous $\mathrm{MgSO}_{4}$, filtered and concentrated. The residue was purified by flash chromatography to give the desire product 7c (137 mg, 55\% yield) as a white solid. $\mathrm{R}_{\mathrm{f}} 0.25$ (Hexane). $\mathrm{mp} 75-76^{\circ} \mathrm{C}$; IR (NaCl) v 3082, 3055, 1674, 1574, 1474, 1446, 1389, 1203, $1012 \mathrm{~cm}^{-1} ;{ }^{1} \mathrm{H} \mathrm{NMR}\left(400 \mathrm{MHz}, \mathrm{CDCl}_{3}\right) \delta 8.03(\mathrm{dd}, J=8.4,1.2 \mathrm{~Hz}, 2 \mathrm{H}), 7.62(\mathrm{t}$, $J=7.4 \mathrm{~Hz}, 1 \mathrm{H}), 7.50(\mathrm{t}, J=7.8 \mathrm{~Hz}, 2 \mathrm{H}), 7.47-7.41(\mathrm{~m}, 4 \mathrm{H}) ;{ }^{13} \mathrm{C} \mathrm{NMR}\left(101 \mathrm{MHz}, \mathrm{CDCl}_{3}\right) \delta 189.5,136.2$, 135.9, 133.8, 129.4, 128.7, 127.4, 125.7; HRMS (ESI, $\mathrm{M}+\mathrm{Na}^{+}$) calculated for $\mathrm{C}_{13} \mathrm{H}_{9} \mathrm{ClNaOS} 270.9960$, found 270.9965 .

S-Dodecyl 4-chlorobenzothioate (7d). To a solution of thiol $\mathbf{6 a}(240 \mu \mathrm{L}, 1 \mathrm{mmol})$, aldehyde $5 \mathbf{b}(703 \mu \mathrm{L}$, $5 \mathrm{mmol})$, tert-butyl hydroperoxide $(277 \mu \mathrm{L}, 2 \mathrm{mmol})$, and ionic liquid $1 \mathrm{~d}(9.7 \mathrm{mg}, 0.025 \mathrm{mmol})$ were stirred at $120^{\circ} \mathrm{C}$ for one hour in a sealed tube. After cooling, the reaction mixture was extracted with ethyl acetate $(3 \times 20 \mathrm{~mL})$. The combined organic layers were dried over anhydrous $\mathrm{MgSO}_{4}$, filtered, and concentrated. The residue was purified by flash chromatography to give the desire product $7 \mathbf{d}(248$ $\mathrm{mg}, 73 \%)$ as a colorless liquid. $\mathrm{R}_{\mathrm{f}} 0.28$ (Hexane). IR $(\mathrm{NaCl}) \mathrm{v} 2925,2854,1913,1825,1785,1668,1589$, 1464, $1092 \mathrm{~cm}^{1} ;{ }^{1} \mathrm{H}$ NMR $\left(400 \mathrm{MHz}, \mathrm{CDCl}_{3}\right) \delta 7.90(\mathrm{~d}, J=8.8 \mathrm{~Hz}, 2 \mathrm{H}), 7.41(\mathrm{~d}, J=8.8 \mathrm{~Hz}, 2 \mathrm{H}), 3.07(\mathrm{t}$, $J=7.4 \mathrm{~Hz}, 2 \mathrm{H}$ ), 1.67 (quint, $J=7.4 \mathrm{~Hz}, 2 \mathrm{H}$ ), 1.42 (quint, $J=7.2 \mathrm{~Hz}, 2 \mathrm{H}), 1.26(\mathrm{~s}, 16 \mathrm{H}), 0.88(\mathrm{t}, J=7.0 \mathrm{~Hz}$, 
3H); ${ }^{13} \mathrm{C} \mathrm{NMR}\left(101 \mathrm{MHz}, \mathrm{CDCl}_{3}\right) \delta$ 190.9, 139.5, 135.5, 128.8, 128.5, 31.9, 29.6, 29.56, 29.5, 29.3, 29.2, 29.1, 28.9, 22.7, 14.1; HRMS (ESI, $\mathrm{M}+\mathrm{H}^{+}$) calculated for $\mathrm{C}_{19} \mathrm{H}_{30} \mathrm{ClOS} 341.1706$, found 341.1705.

S-Decyl 4-chlorobenzothioate (7e). To a solution of thiol $\mathbf{6 b}(221 \mu \mathrm{L}, 1 \mathrm{mmol})$, aldehyde $5 \mathbf{b}(703 \mathrm{mg}, 5$ mmol), tert-butyl hydroperoxide $(277 \mu \mathrm{L}, 2 \mathrm{mmol})$, and ionic liquid $1 \mathbf{d}(9.7 \mathrm{mg}, 0.025 \mathrm{mmol})$ were stirred at $120^{\circ} \mathrm{C}$ for one hour in a sealed tube. After cooling, the reaction mixture was extracted with ethyl acetate $(3 \times 20 \mathrm{~mL})$. The combined organic layers were dried over anhydrous $\mathrm{MgSO}_{4}$, filtered, and concentrated. The residue was purified by flash chromatography to give the desire product $7 \mathbf{e}$ (228 $\mathrm{mg}, 73 \%)$ as a colorless liquid. $\mathrm{R}_{\mathrm{f}} 0.31$ (Hexane). IR ( $\left.\mathrm{NaCl}\right)$ v 2955, 2926, 2854, 1668, 1589, 1464, 1092 $\mathrm{cm}^{-1},{ }^{1} \mathrm{H}$ NMR $\left(400 \mathrm{MHz}, \mathrm{CDCl}_{3}\right) \delta 7.90(\mathrm{~d}, J=8.4 \mathrm{~Hz}, 2 \mathrm{H}), 7.41(\mathrm{~d}, J=8.4 \mathrm{~Hz}, 2 \mathrm{H}), 3.06(\mathrm{t}, J=7.2 \mathrm{~Hz}$, $2 \mathrm{H}$ ), 1.66 (quint, $J=7.4 \mathrm{~Hz}, 2 \mathrm{H}), 1.41$ (quint, $J=7.2 \mathrm{~Hz}, 2 \mathrm{H}), 1.26(\mathrm{~s}, 12 \mathrm{H}), 0.88(\mathrm{t}, J=6.8 \mathrm{~Hz}, 3 \mathrm{H}) ;{ }^{13} \mathrm{C}$ NMR $\left(101 \mathrm{MHz}, \mathrm{CDCl}_{3}\right) \delta$ 191.0, 139.5, 135.6, 128.8, 128.5, 31.9, 29.5, 29.47, 29.3, 29.2, 29.1, 28.9, 22.7, 14.1; HRMS (ESI, $\mathrm{M}+\mathrm{H}^{+}$) calculated for $\mathrm{C}_{17} \mathrm{H}_{26} \mathrm{ClOS} 313.1393$, found 313.1355.

S-Dodecyl 4-methoxybenzothioate (7f). To a solution of thiol $\mathbf{6 a}(239 \mu \mathrm{L}, 1 \mathrm{mmol})$, aldehyde $5 \mathrm{c}(609 \mu \mathrm{L}$, $5 \mathrm{mmol})$, tert-butyl hydroperoxide $(276 \mu \mathrm{L}, 2 \mathrm{mmol})$, and ionic liquid $1 \mathrm{~d}(10 \mathrm{mg}, 0.025 \mathrm{mmol})$ were stirred at $140{ }^{\circ} \mathrm{C}$ for one hour in a sealed tube. After cooling, the reaction mixture was extracted with ethyl acetate $(3 \times 20 \mathrm{~mL})$. The combined organic layers were dried over anhydrous $\mathrm{MgSO}_{4}$, filtered, and concentrated. The residue was purified by flash chromatography to give the desire product $\mathbf{7 f}$ (255 mg, 76\%) as a colorless liquid. $\mathrm{R}_{\mathrm{f}} 0.20$ (hexane); $\mathrm{IR}(\mathrm{NaCl}) \mathrm{v} 2924,2853,1658,1602,1508,1463$, 1259,$837 ;{ }^{1} \mathrm{H}$ NMR $\left(400 \mathrm{MHz}, \mathrm{CDCl}_{3}\right) \delta 7.93(\mathrm{~d}, J=9.2 \mathrm{~Hz}, 2 \mathrm{H}), 6.89(\mathrm{~d}, J=8.8 \mathrm{~Hz}, 2 \mathrm{H}), 3.83(\mathrm{~s}, 3 \mathrm{H})$, $3.03(\mathrm{t}, J=7.4 \mathrm{~Hz}, 2 \mathrm{H}), 1.68-1.60(\mathrm{~m}, 2 \mathrm{H}), 1.44-1.36(\mathrm{~m}, 2 \mathrm{H}), 1.24(\mathrm{~s}, 16 \mathrm{H}), 0.86(\mathrm{t}, J=6.8 \mathrm{~Hz}, 3 \mathrm{H}) ;{ }^{13} \mathrm{C}$ NMR $\left(100 \mathrm{MHz}, \mathrm{CDCl}_{3}\right) \delta 190.4,163.5,130.0,129.2,113.5,55.3,31.9,29.6,29.58,29.54,29.5,29.3,29.1$, 28.9, 28.8, 22.6, 14.0; HRMS (ESI, $\mathrm{M}+\mathrm{Na}^{+}$) calculated for $\mathrm{C}_{20} \mathrm{H}_{32} \mathrm{NaO}_{2} \mathrm{~S} 359.2020$, found 359.2032.

S-Decyl 4-methoxybenzothioate $(7 \mathrm{~g})$. To a solution of thiol $\mathbf{6 b}(207 \mu \mathrm{L}, 1 \mathrm{mmol})$, aldehyde $5 \mathbf{c}(609 \mu \mathrm{L}$, $5 \mathrm{mmol})$, tert-butyl hydroperoxide $(276 \mu \mathrm{L}, 2 \mathrm{mmol})$, and ionic liquid $1 \mathrm{~d}(10 \mathrm{mg}, 0.025 \mathrm{mmol})$ were stirred at $120^{\circ} \mathrm{C}$ for one hour in a sealed tube. After cooling, the reaction mixture was extracted with ethyl acetate $(3 \times 20 \mathrm{~mL})$. The combined organic layers were dried over anhydrous $\mathrm{MgSO}_{4}$, filtered, and concentrated. The residue was purified by flash chromatography to give the desire product $7 \mathrm{~g}$ (226 mg, 73\%) as a colorless liquid. $\mathrm{R}_{\mathrm{f}} 0.25$ (hexane); $\mathrm{IR}(\mathrm{NaCl})$ v 2925, 2854, 1658, 1602, 1508, 1463, 1259, 838; ${ }^{1} \mathrm{H}$ NMR $\left(400 \mathrm{MHz}, \mathrm{CDCl}_{3}\right) \delta 7.93(\mathrm{~d}, J=8.8 \mathrm{~Hz}, 2 \mathrm{H}), 6.90(\mathrm{~d}, J=8.8 \mathrm{~Hz}, 2 \mathrm{H}), 3.84(\mathrm{~s}, 3 \mathrm{H})$, $3.02(\mathrm{t}, J=7.4 \mathrm{~Hz}, 2 \mathrm{H}), 1.68-1.60(\mathrm{~m}, 2 \mathrm{H}), 1.44-1.35(\mathrm{~m}, 2 \mathrm{H}), 1.24(\mathrm{~s}, 12 \mathrm{H}), 0.86(\mathrm{t}, J=6.8 \mathrm{~Hz}, 3 \mathrm{H}) ;{ }^{13} \mathrm{C}$ NMR $\left(100 \mathrm{MHz}, \mathrm{CDCl}_{3}\right) \delta 190.4,163.5,130.0,129.2,113.6,55.3,31.8,29.6,29.5,29.4,29.2,29.1,28.9,28.8$, 22.6, 14.0; HRMS (ESI, $\mathrm{M}+\mathrm{Na}^{+}$) calculated for $\mathrm{C}_{18} \mathrm{H}_{28} \mathrm{NaO}_{2} \mathrm{~S} 331.1708$, found 331.1702.

S-(4-Chlorophenyl) 4-methoxybenzothioate (7h). To a solution of thiol $\mathbf{6 c}(145 \mathrm{mg}, 1 \mathrm{mmol})$, aldehyde $5 \mathrm{c}$ $(609 \mu \mathrm{L}, 5 \mathrm{mmol})$, tert-butyl hydroperoxide ( $276 \mu \mathrm{L}, 2 \mathrm{mmol})$, and ionic liquid $\mathbf{1 d}(10 \mathrm{mg}, 0.025 \mathrm{mmol})$ were stirred at $120^{\circ} \mathrm{C}$ for one hour in a sealed tube. After cooling, the reaction mixture was extracted with ethyl acetate $(3 \times 20 \mathrm{~mL})$. The combined organic layers were dried over anhydrous $\mathrm{MgSO}_{4}$, filtered and concentrated. The residue was purified by flash chromatography to give the desire product $7 \mathrm{~h}$ (142 mg, 51\%) as a white solid. $\mathrm{R}_{\mathrm{f}} 0.45$ (EtOAc /Hex = 1/4); mp 96-97 ${ }^{\circ} \mathrm{C}$; IR (NaCl) v 1690, 1660, 1602, 1508, 1261, 833; ${ }^{1} \mathrm{H}$ NMR $\left(400 \mathrm{MHz}, \mathrm{CDCl}_{3}\right) \delta 7.98(\mathrm{~d}, J=9.2 \mathrm{~Hz}, 2 \mathrm{H}), 7.41(\mathrm{~d}, J=3.2 \mathrm{~Hz}, 4 \mathrm{H}), 6.94(\mathrm{~d}, J$ $=8.8 \mathrm{~Hz}, 2 \mathrm{H}), 3.84(\mathrm{~s}, 3 \mathrm{H}) . ;{ }^{13} \mathrm{C} \mathrm{NMR}\left(100 \mathrm{MHz}, \mathrm{CDCl}_{3}\right) \delta$ 187.7, 164.0, 136.2, 135.6, 129.6, 129.2, 128.9, 126.0, 113.8, 55.4; HRMS (ESI, $\mathrm{M}+\mathrm{Na}^{+}$) calculated for $\mathrm{C}_{14} \mathrm{H}_{11} \mathrm{ClNaO}_{2} \mathrm{~S} 301.0066$, found 301.0059.

S-Dodecyl hexanethioate (7i). To a solution of thiol $\mathbf{6 a}(239 \mu \mathrm{L}, 1 \mathrm{mmol})$, aldehyde $5 \mathbf{d}(615 \mu \mathrm{L}, 5 \mathrm{mmol})$, tert-butyl hydroperoxide ( $276 \mu \mathrm{L}, 2 \mathrm{mmol})$, and ionic liquid $1 \mathrm{~d}(10 \mathrm{mg}, 0.025 \mathrm{mmol})$ were stirred at $120^{\circ} \mathrm{C}$ for one hour in a sealed tube. After cooling, the reaction mixture was extracted with ethyl acetate $(3 \times 20 \mathrm{~mL})$. The combined organic layers were dried over anhydrous $\mathrm{MgSO}_{4}$, filtered, and concentrated. The residue was purified by flash chromatography to give the desire product $7 \mathbf{i}(240 \mathrm{mg}$, $80 \%)$ as a colorless liquid. $\mathrm{R}_{\mathrm{f}} 0.35$ (hexane); $\mathrm{IR}(\mathrm{NaCl})$ v 2957, 2926, 2855, 1693, 1464, 1121; ${ }^{1} \mathrm{H}$ NMR $\left(400 \mathrm{MHz}, \mathrm{CDCl}_{3}\right) \delta 2.85(\mathrm{t}, J=7.4 \mathrm{~Hz}, 2 \mathrm{H}), 2.52(\mathrm{t}, J=7.6 \mathrm{~Hz}, 2 \mathrm{H}), 1.69-1.61(\mathrm{~m}, 2 \mathrm{H}), 1.59-1.51(\mathrm{~m}, 2 \mathrm{H})$, 
1.37-1.27 (m, 8H), 1.25 (s, 14H), 0.90-0.85 (m, 6H); $\left.{ }^{13} \mathrm{C} \mathrm{NMR} \mathrm{(100} \mathrm{MHz,} \mathrm{CDCl}_{3}\right) \delta$ 199.5, 199.3, 44.0, 31.9, 31.0, 29.6, 29.5, 29.4, 29.3, 29.1, 28.8, 28.7, 25.3, 22.6, 22.3, 14.0, 13.8; HRMS (FAB, $\mathrm{M}+\mathrm{H}^{+}$) calculated for $\mathrm{C}_{18} \mathrm{H}_{37} \mathrm{OS} 301.2565$, found 301.2568.

S-Decyl hexanethioate (7j). To a solution of thiol $\mathbf{6 b}(221 \mu \mathrm{L}, 1 \mathrm{mmol})$, aldehyde $5 \mathbf{d}(615 \mu \mathrm{L}, 5 \mathrm{mmol})$, tert-butyl hydroperoxide ( $277 \mu \mathrm{L}, 2 \mathrm{mmol})$, and ionic liquid $1 \mathrm{~d}(9.7 \mathrm{mg}, 0.025 \mathrm{mmol})$ were stirred at $120^{\circ} \mathrm{C}$ for one hour in a sealed tube. After cooling, the reaction mixture was extracted with ethyl acetate $(3 \times 20 \mathrm{~mL})$. The combined organic layers were dried over anhydrous $\mathrm{MgSO}_{4}$, filtered, and concentrated. The residue was purified by flash chromatography to give the desire product $7 \mathbf{j}$ (194 $\mathrm{mg}, 71 \%$ ) as a colorless liquid. $\mathrm{R}_{\mathrm{f}} 0.40$ (Hexane). IR ( $\left.\mathrm{NaCl}\right)$ v 2927, 2855, 2731, 2671, 1693, 1463, $1030 \mathrm{~cm}^{-1} ;{ }^{1} \mathrm{H}$ NMR $\left(400 \mathrm{MHz}, \mathrm{CDCl}_{3}\right) \delta 2.85(\mathrm{t}, J=7.4 \mathrm{~Hz}, 2 \mathrm{H}), 2.52(\mathrm{t}, J=7.6 \mathrm{~Hz}, 2 \mathrm{H}), 1.65$ (quint, $\left.J=7.4 \mathrm{~Hz}, 2 \mathrm{H}\right), 1.55$ (quint, $J=7.3 \mathrm{~Hz}, 2 \mathrm{H}), 1.30(\mathrm{~m}, 8 \mathrm{H}), 1.25(\mathrm{~s}, 10 \mathrm{H}), 0.88(\mathrm{q}, J=6.4 \mathrm{~Hz}, 6 \mathrm{H}) ;{ }^{13} \mathrm{C} \mathrm{NMR}\left(101 \mathrm{MHz}, \mathrm{CDCl}_{3}\right)$

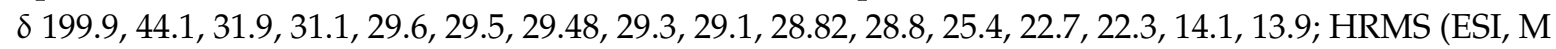
$+\mathrm{Na}^{+}$) calculated for $\mathrm{C}_{16} \mathrm{H}_{32} \mathrm{NaOS} 295.2072$, found 295.2072.

S-Dodecyl octanethioate (7k). To a solution of thiol $\mathbf{6 a}(240 \mu \mathrm{L}, 1 \mathrm{mmol})$, aldehyde $5 \mathbf{e}(781 \mu \mathrm{L}, 5 \mathrm{mmol})$, tert-butyl hydroperoxide ( $277 \mu \mathrm{L}, 2 \mathrm{mmol})$, and ionic liquid $1 \mathrm{~d}(9.7 \mathrm{mg}, 0.025 \mathrm{mmol})$ were stirred at 120 ${ }^{\circ} \mathrm{C}$ for one hour in a sealed tube. After cooling, the reaction mixture was extracted with ethyl acetate (3 $\times 20 \mathrm{~mL}$ ). The combined organic layers were dried over anhydrous $\mathrm{MgSO}_{4}$, filtered, and concentrated. The residue was purified by flash chromatography to give the desire product $7 \mathbf{k}$ ( $223 \mathrm{mg}, 68 \%$ yield) as a colorless liquid. $\mathrm{R}_{\mathrm{f}} 0.48$ (Hexane). IR $(\mathrm{NaCl}) \mathrm{v} 2923,2855,1694,1463,1377,1043 \mathrm{~cm}^{-1} ;{ }^{1} \mathrm{H}$ NMR $(400$ $\left.\mathrm{MHz}, \mathrm{CDCl}_{3}\right) \delta 2.83(\mathrm{t}, J=7.2 \mathrm{~Hz}, 2 \mathrm{H}), 2.50(\mathrm{t}, J=7.4 \mathrm{~Hz}, 2 \mathrm{H}), 1.69-1.58(\mathrm{~m}, 2 \mathrm{H}), 1.58-1.48(\mathrm{~m}, 2 \mathrm{H}), 1.23$ $(\mathrm{s}, 26 \mathrm{H}), 0.85(\mathrm{t}, J=6.6 \mathrm{~Hz}, 6 \mathrm{H}) ;{ }^{13} \mathrm{C} \mathrm{NMR}\left(101 \mathrm{MHz}, \mathrm{CDCl}_{3}\right) \delta 199.6,44.1,31.9,31.6,29.6,29.58,29.55$, 29.5, 29.3, 29.1, 28.9, 28.88, 28.8, 28.7, 25.7, 22.7, 22.6, 14.1, 14.0; HRMS (FAB, $\mathrm{M}+\mathrm{H}^{+}$) calculated for $\mathrm{C}_{20} \mathrm{H}_{41} \mathrm{OS} 329.2878$, found 329.2878.

S-Decyl octanethioate (7l). To a solution of thiol $6 \mathbf{b}(221 \mu \mathrm{L}, 1 \mathrm{mmol})$, aldehyde $5 \mathbf{e}(781 \mu \mathrm{L}, 5 \mathrm{mmol})$, tert-butyl hydroperoxide ( $277 \mu \mathrm{L}, 2 \mathrm{mmol})$, and ionic liquid $1 \mathrm{~d}(9.7 \mathrm{mg}, 0.025 \mathrm{mmol})$ were stirred at $120^{\circ} \mathrm{C}$ for one hour in a sealed tube. After cooling, the reaction mixture was extracted with ethyl acetate $(3 \times 20 \mathrm{~mL})$. The combined organic layers were dried over anhydrous $\mathrm{MgSO}_{4}$, filtered, and concentrated. The residue was purified by flash chromatography to give the desire product 71 (192 $\mathrm{mg}, 64 \%)$ as a colorless liquid. $\mathrm{R}_{\mathrm{f}} 0.35$ (Hexane). IR ( $\left.\mathrm{NaCl}\right)$ v 2956, 2926, 2855, 2730, 2671, 1693, 1464, $1124 \mathrm{~cm}^{-1} ;{ }^{1} \mathrm{H}$ $\operatorname{NMR}\left(400 \mathrm{MHz}, \mathrm{CDCl}_{3}\right) \delta 2.85(\mathrm{t}, J=7.2 \mathrm{~Hz}, 2 \mathrm{H}), 2.52(\mathrm{t}, J=7.4 \mathrm{~Hz}, 2 \mathrm{H}), 1.64$ (quint, $J=7.2 \mathrm{~Hz}, 2 \mathrm{H}$ ), 1.55 (quint, $J=7.3 \mathrm{~Hz}, 2 \mathrm{H}), 1.36-1.26(\mathrm{~m}, 10 \mathrm{H}), 1.25(\mathrm{~s}, 12 \mathrm{H}), 0.87(\mathrm{t}, J=7.0 \mathrm{~Hz}, 6 \mathrm{H}) ;{ }^{13} \mathrm{C} \mathrm{NMR}(101$ $\left.\mathrm{MHz}, \mathrm{CDCl}_{3}\right) \delta 199.8,44.1,31.9,31.6,29.6,29.5,29.48,29.3,29.1,28.9,28.8,28.79,25.7,22.7,22.6,14.1$, 14.0; HRMS (ESI, $\mathrm{M}+\mathrm{Na}^{+}$) calculated for $\mathrm{C}_{18} \mathrm{H}_{36} \mathrm{NaOS} 323.2385$, found 323.2373.

\section{Conclusions}

The designed ionic liquid $\mathbf{1 d}$ were successfully catalyze the Friedel-Crafts acylation reaction and thioesterification reaction. It provides good to excellent yield in both the reactions under optimal conditions. The ionic liquid 1d exhibits the dual Brønsted and Lewis acidic property. The catalyst showed high atom economy, high thermal stability, and could be recycled with minor loss in activity and also moisture insensitive. The catalyst shows some limitations, which exhibited good solubility in many organic solvents and deionized water, but not in hexane.

Supplementary Materials: ${ }^{1} \mathrm{H}$ NMR and ${ }^{13} \mathrm{C}$ NMR are available online.

Author Contributions: S.-Y.L. and W.-Y.H. designed the research. H.-R.W. analyzed the data. Y.-J.L., M.T., Y.-P.W., M.-W.H., W.L. and M.L. were prepared the compounds. S.-H.C. and W.-T.C. prepared ionic liquid. M.T. wrote the manuscript with the help of D.M.R. All authors have read and agreed to the published version of the manuscript.

Funding: This research was funded by National Chung Hsing University, and Chia Nan University of Pharmacy and Science. 
Acknowledgments: The authors thank the Ministry of Science and Technology in Taiwan (MOST 106-2113-M-005-007 and 107-2113-M-005-021 for S.-Y.L. and MOST 106-2221-E-041-004 for W.-Y.H.), National Chung Hsing University, and Chia Nan University of Pharmacy and Science for financial support.

Conflicts of Interest: The authors declare no conflict of interest. The funders had no role in the design of the study; in the collection, analyses, or interpretation of data; in the writing of the manuscript, or in the decision to publish the results.

\section{References}

1. Natalia, V.P.; Kenneth, R.S. Application of ionic liquids in chemical industry. Chem. Soc. Rev. 2008, 37, 123-150.

2. Shi, R.; Wang, Y.-T. Dual ionic and organic nature of ionic liquids. Sci. Rep. 2016, 6, 19644. [CrossRef]

3. Anderson, J.L.; Ding, J.; Welton, T.; Armstrong, D.W. Characterizing ionic liquids on the basis of multiple solvation interactions. J. Am. Chem. Soc. 2002, 124, 14247-14254. [CrossRef] [PubMed]

4. Weyershausen, B.; Lehmann, K. Industrial application of ionic liquids as performance additives. Green. Chem. 2005, 7, 15-19. [CrossRef]

5. Lei, Z.; Chen, B.; Koo, Y.-M.; MacFarlane, D.R. Introduction: Ionic liquids. Chem. Rev. 2017, 117, 6633-6635. [CrossRef] [PubMed]

6. Creary, X.; Willis, E.D.; Gagnon, M. Carbocation-forming reactions in ionic liquids. J. Am. Chem. Soc. 2005, 127, 18114-18120. [CrossRef]

7. Mallakpour, S.; Dinari, M. Green Solvents II, Properties and Applications of Ionic Liquids; Inamuddin, A.M., Ed.; Springer: New York, NY, USA, 2012; pp. 1-32.

8. Neves, C.M.S.S.; Freire, M.G.; Coutinho, J.A.P. Improved recovery of ionic liquids from contaminated aqueous streams using aluminium-based salts. RSC Adv. 2012, 2, 10882-10890. [CrossRef]

9. Doorslaer, C.V.; Glas, D.; Peeters, A.; Odena, A.C.; Vankelecom, I.; Binnemans, K.; Mertensa, P.; Vos, D.D. Product recovery from ionic liquids by solvent-resistant nanofiltration; application to ozonation of acetals and methyl oleate. Green Chem. 2010, 12, 1726-1733. [CrossRef]

10. Faßbach, T.A.; Kirchmann, R.; Behr, A.; Vorholt, A.J. Recycling of homogeneous catalysts in reactive ionic liquids-solvent-free amino functionalization of alkenes. Green Chem. 2017, 19, 5243-5249. [CrossRef]

11. Ladnak, V.; Hofmann, N.; Brausch, N.; Wasserscheida, P. Continuous, ionic liquids-catalysed propylation of toluene in a liquid-liquid biphasic reaction mode using a loop reactor concept. Adv. Synth. Catal. 2007, 349, 719-726. [CrossRef]

12. Canales, R.I.; Brennecke, J.F. Comparison of ionic liquids to conventional organic solvents for extraction of aromatics from aliphatics. J. Chem. Eng. Data 2016, 61, 1685-1699. [CrossRef]

13. Dyson, P.J. Transition metal chemistry in ionic liquids. Transition Met. Chem. 2002, 27, 353-358. [CrossRef]

14. Chinnappan, A.; Kim, H. Transition metal based ionic liquid (bulk and nanofiber composites) use as catalyst for reduction of aromatic nitro compounds under mild conditions. RSC Adv. 2013, 3, 3399-3406. [CrossRef]

15. Zhao, Q.; Yin, M.; Zhang, A.P.; Prescher, S.; Antonietti, M.; Yuan, J. Helically structured nanoporous poly (ionic liquids) membranes: Facile preparation and application in fiber-optic pH sensing. J. Am. Chem. Soc. 2013, 135, 5549-5552. [CrossRef] [PubMed]

16. Hallett, J.P.; Pollet, P.; Liotta, C.L.; Eckert, C.A. Reversible in situ catalyst formation. Acc. Chem. Res. 2008, 41, 458-467. [CrossRef] [PubMed]

17. William, S.B.; Guillaume, P.; André, B.C. Chemoselective synthesis of ketones and ketimines by addition of organometallic reagents to secondary amides. Nat. Chem. 2012, 4, 228-234.

18. Maji, A.; Dahiya, A.; Lu, G.; Bhattacharya, T.; Brochetta, M.; Zanoni, G.; Liu, P.; Maiti, D. H-bonded reusable template assisted para-selective ketonization using soft electrophilic vinyl ethers. Nat. Commun. 2018, 9, 1-10. [CrossRef]

19. Li, M.-H.; Shang, M.; Xu, H.; Wang, X.; Dai, H.-X.; Yu, J.-Q. Remote Para-C-H acetoxylation of electron-deficient arenes. Org. Lett. 2019, 21, 540-544. [CrossRef]

20. Gmouh, S.; Yang, H.; Vaultier, M. Activation of bismuth(III) derivatives in ionic liquids: Novel and recyclable catalytic systems for Friedel—Crafts acylation of aromatic compounds. Org. Lett. 2003, 5, 2219-2222. [CrossRef] 
21. Prakash, G.K.S.; Farzaneh, P.; Aditya, K.; Arjun, N.; Fang, W.; Golam, R.; Thomas, M.; George, A.O. Taming of superacids: PVP triflic acid as an effective solid triflic acid equivalent for Friedel—Crafts hydroxyalkylation and acylation. J. Fluor. Chem. 2014, 171, 102-112. [CrossRef]

22. Tran, P.H.; Hansen, P.E.; Hoang, H.M.; Chau, D.K.N.; Le, T.N. Indium triflate in 1-isobutyl-3-methylimidazolium dihydrogenphosphate: An efficient and green catalytic system for Friedel-Crafts acylation. Tetrahedron Lett. 2015, 56, 2187-2192. [CrossRef]

23. Olah, G.A.; Malhotra, R.; Narang, S.C.; Olah, J.A. Heterogeneous Catalysis by Solid Superacids. 14. Perfluorinated Resinsulfonic Acid Catalyzed Friedel—Crafts Acylation of Benzene and Substituted Benzenes. Synthesis 1978, 672-673. [CrossRef]

24. Miles, W.H.; Nutaitis, C.F.; Anderton, C.A. Iron(III) Chloride as a Lewis Acid in the Friedel—Crafts Acylation Reaction. J. Chem. Educ. 1996, 73, 272. [CrossRef]

25. Li, Z.; Li, G.; Jiang, L.; Li, J.; Sun, G.; Xia, C.; Li, F.-W. Ionic liquids as precursor for efficient mesoporous iron-nitrogen doped oxygen reduction electrocatalyst. Angew. Chem. Int. Ed. 2015, 54, 1494-1498. [CrossRef]

26. Han, X.-X.; Du, H.; Hung, C.-T.; Liu, L.-L.; Wu, P.-H.; Ren, D.-H.; Huang, S.-J.; Liu, S.-B. Syntheses of novel halogen-free Brønsted-Lewis acidic ionic liquid catalysts and their applications for synthesis of methyl caprylate. Green Chem. 2015, 17, 499-508. [CrossRef]

27. Wang, H.B.; Yao, N.; Wang, L.; Hu, Y.L. Brønsted-Lewis dual acidic ionic liquid immobilized on mesoporous silica materials as an efficient cooperative catalyst for Mannich reactions. New J. Chem. 2017, 41, 10528-10531. [CrossRef]

28. Ross, J.; Xiao, J. Friedel—Crafts acylation reactions using metal triflates in ionic liquid. Green. Chem. 2002, 4, 129-133. [CrossRef]

29. Earle, M.J.; Hakala, U.; Hardacre, C.; Karkkainen, J.; McAuley, B.J.; Rooney, D.W.; Seddon, K.R.; Thompson, J.M.; Wähälä, K. Chloroindate(III) ionic liquids: Recyclable media for Friedel—Crafts acylation reactions. Chem. Commun. 2005, 903-905. [CrossRef]

30. Ahrens, S.; Peritz, A.; Strassner, T. Tunable aryl alkyl ionic liquids (TAAILs): The next generation of ionic liquids. Angew. Chem. Int. Ed. 2009, 48, 7908-7910. [CrossRef]

31. Huang, Y.-T.; Lu, S.-Y.; Yi, C.-L.; Lee, C.-F. Iron-catalyzed synthesis of thioesters from thiols and aldehydes in water. J. Org. Chem. 2014, 79, 4561-4568. [CrossRef]

32. Nambu, H.; Hata, K.; Matsugi, M.; Kita, Y. The direct synthesis of thioesters using an intermolecular radical reaction of aldehydes with dipentafluorophenyl disulfide in water. Chem. Commun. 2002, 1082-1083. [CrossRef]

33. Nambu, H.; Hata, K.; Matsugi, M.; Kita, Y. Efficient Synthesis of thioesters and amides from aldehydes by using an intermolecular radical reaction in water. Chem. Eur. J. 2005, 11, 719-727. [CrossRef]

34. Uno, T.; Inokuma, T.; Takemoto, Y. NHC-catalyzed thioesterification of aldehydes by external redox activation. Chem. Commun. 2012, 48, 1901-1903. [CrossRef]

35. Bandgar, B.P.; Bandgar, S.B.; Korbad, B.L.; Sawant, S.S. Dess-Martin periodinane mediated synthesis of thioesters from aldehydes. Tetrahedron Lett. 2007, 48, 1287-1290. [CrossRef]

36. Jhuang, H.-S.; Liu, Y.-W.; Reddy, D.M.; Tzeng, Y.-Z.; Lin, W.-Y.; Lee, C.-F. Microwave-assisted Synthesis of thioesters from aldehydes and thiols in water. Chin. Chem. Soc. 2018, 65, 24-27. [CrossRef]

37. Chang, J.C.; Yang, C.H.; Sun, I.W.; Ho, W.Y.; Wu, T.-Y. Synthesis and properties of magnetic aryl-imidazolium ionic liquids with dual Brønsted/Lewis acidity. Materials 2018, 11, 2539. [CrossRef]

38. Yang, C.H.; Chang, J.C.; Wu, T.Y.; Sun, I.W.; Wu, J.H.; Ho, W.Y. Novel aryl-imidazolium ionic liquids with dual Brønsted/Lewis acidity as both solvents and catalysts for Friedel-Crafts alkylation. Appl. Sci. 2019, 9, 4743. [CrossRef]

Sample Availability: Samples of the compounds are not available from the authors. 